\title{
A HELYIDENTITÁS MÉRÉSE IDENTITÁSORIENTÁCIÓKÉNT
}

\author{
BERZE IVÁN ZSOLT ${ }^{1,2 *}$ - DÚLL ANDREA ${ }^{2,3}$
}

\author{
${ }^{1}$ Eötvös Loránd Tudományegyetem Pszichológiai Doktori Iskola, Budapest, Magyarország \\ ${ }^{2}$ Eötvös Loránd Tudományegyetem Ember-Környezet Tranzakció Intézet, \\ Budapest, Magyarország \\ ${ }^{3}$ BME Gazdaság- és Társadalomtudományi Kar Szociológia és Kommunikáció Tanszék, \\ Budapest, Magyarország \\ E-mail: berze.ivan.zsolt@ppk.elte.hu
}

Benyújtva: 2020. július 19. - Elfogadva: 2021. május 11.

A helyidentitás környezetpszichológiai fogalmát új megközelitésként személyiségpszichológiai szinten vizsgáló kutatássorozatunk második lépésében azt feltételeztük, hogy az egyetemista vizsgálati személyekkel elvégzett elsố mérés eredményeire (Berze és Dúll, 2018) alapozva létrehozott kérdôivünkkel felnôtt mintán is megbizhatóan mérhetố a helyidentitás identitásorientációként (tehát az egyéni különbségek abban, hogy a helyekkel kiépitett kapcsolat milyen mértékben fontos a személyek számára önmaguk meghatározásában), továbbá hogy az új kérdốivünk a korábbi változatnál megbizhatóbban méri az eredeti angol nyelvú kérdốivben (AIQ-IV, Cheek, Smith és Tropp, 2002) szereplö négy (személyes, társas/nyilvános, kollektív és kapcsolati) identitásorientációt is.

Módszer: Feltételezésünk vizsgálatához az AIQ-IV kérdốv magyarra fordított, a helyidentitásra vonatkozó, általunk megfogalmazott tételekkel bốvített, elözó kutatási lépésünkben használt második változatán végeztünk módositásokat annak eredményeire épülô szakmai és módszertani megfontolások alapján. A kérdốtvet jelen kutatásban két változatban felnôtt mintákon $(n=177,432)$ teszteltük, majd mindkét esetben faktoranalizist végeztünk. A második kérdôivváltozat az ebben a kutatásban használt elsố verzió eredményei alapján elvégzett módosítások nyomán született.

Eredmények: A helyidentitás identitásorientációként történô mérésének helytállóságát a felnôtt mintán felvett módositott kérdốv adatai és azok statisztikai elemzése igazolta, továbbá az elôző kutatási lépés kérdôivén végzett módositások nagyrészt elérték céljukat, hiszen - bár nem tökéletesen, de - igen nagy részben fedi a jelen kutatásban kapott faktorstruktúra az eredeti kérdốv skáláit.

Következtetések: A kapott eredmények újabb lépést jelentenek a helyidentitás fogalmának árnyaltabb értelmezéséhez. További lépésekben megkezdtük a második változat angliai felnốt mintán történô felvételét, továbbá tervezzük a magyar változat további pontositását, valamint a finomított változat felvételét a helyidentitás aspektusait a személyiség szintjén mérố kérdôiv mellett kiegyenlítettebb nemi és életkori eloszlású felnôtt hazai mintán.

Kulcsszavak: helyidentitás, (én)identitás, énfogalom, identitásorientáció, kérdôívfejlesztés

Levelezố szerzô 


\section{BEVEZETÉS}

Korábbi vizsgálatunkban (Berze és Dúll, 2018) a helyidentitás (Proshansky, 1978; Proshansky, Fabian és Kaminoff, 1983; Dúll, 1996) környezetpszichológiai fogalmát új, személyiségpszichológiai megközelítésben vizsgáltuk. Jelen kutatásunkat szintén e megközelítésben, a korábbi vizsgálat eredményeinek és az azokon alapuló módszertani megfontolásoknak (Berze és Dúll, 2019) a figyelembevételével végeztük. Elsôdleges célunk a helyidentitást mint identitásorientációt megfelelően mérô magyar nyelvú kérdôív kialakítása.

A helyidentitás a személy és környezete kölcsönkapcsolata révén alakul ki, amikor a személy számára fontos helyek az identitása meghatározójává, részévé, ezáltal pedig mind környezeti, mind társas viselkedésének befolyásolóivá is válnak. A helyidentitást az eddigi kutatásokban elsôsorban a helyek szintjén vizsgálták, konkrét/kedvenc helyekre vonatkozóan. Kutatássorozatunkban újszerú nézôpontként a helyidentitást a személyiség felōl közelítjük meg: konkrét helyek vizsgálata helyett a helyekkel való kapcsolat meghatározó voltának egyéni különbségeire fókuszálunk. Ez a nézôpont bôvítheti mind az identitásstruktúrával, a szociofizikai környezet abban elfoglalt helyével, továbbá a környezettel való kapcsolat egyéni jellemzóivel, különbségeivel, mind pedig a helyidentitás összetevôivel, aspektusaival kapcsolatos tudást. A helyidentitás orientációként történô vizsgálata hozzájárulhat a helyidentitás fogalmának mélyebb, illetve árnyaltabb megértéséhez, illetve gyakorlati téren a személy-környezet összeillés ${ }^{1}$ vizsgálatához és annak ember-környezet tranzakcióelemzés során feltárt esetleges nehézségeinek javításához, változásainak kezeléséhez egyéni szinten is.

\section{Az identitásorientáció}

Az identitás ${ }^{2}$ bizonyos aspektusai orientációként történô mérésének alapját az identitással, pontosabban annak tartalmi (öndefiníciós) összetevôivel kapcsolatos elképzelésekben jelen lévô személyes-társas dichotómia adta. A személyes és a társas identitás - amelyek közül Miller (1963, idézi Cheek és Briggs, 1982) szerint elóbbi az énrôl alkotott nézeteket, a folytonosság és egyediség érzését, utóbbi a szociális szerepeket és kapcsolatokat tartalmazza - megkülönböztetése számos kutatónál megtalálható, bár a különbségtétel élességére és a kettô viszonyára vonatkozóan nincsen konszenzus a kutatók között (Deaux, 1993). Ez a dichotómia ugyanakkor megtalálható a személyiségpszichológiai elméletekben is, pl. spirituális és szociális én (James, idézi: Greenwald és Pratkanis, 1984/1992), személyes én és kollektív én (Greenwald és Pratkanis, 1984/1992), személyes és személyközi én (Neisser, 1988/1992), nyilvános és személyes éntudatosság (Fenigstein, Scheier és Buss, 1975), személyes, kapcsolati és kollektív én

\footnotetext{
A fogalom definíciójához lásd pl. Kaplan (1983), Edwards, Cable, Williamson, Lambert és Shipp (2006), Dúll (2009), Phillips, Cheng, Yeh és Siu (2010).

Az identitás fogalmát tanulmányunkban és kutatásunkban - miként Jonathan Cheek (1989), a kutatásunkban használt kérdôív egyik fejlesztôje - az eriksoni (1991) értelemben használjuk. Az angol nyelvú szakirodalomban sok esetben szinonimaként használt én, énfogalom és identitás fogalmak viszonyának tisztázásában Oyserman, Elmore és Smith (2012) nyújtanak támpontot.
} 
(Sedikides és Brewer, 2001), az identitás többszörös dimenzióinak elméleti modellje (Jones és McEwen, 2000) és így tovább.

Sampson (1978) Miller két fenti általános kategóriáját, azaz a személyes és a társas identitást alapul véve úgy gondolta, hogy vannak személyek, akik énfogalmuk meghatározásakor inkább a belsố (önmagukban rejlô) aspektusok felé irányulnak, míg mások a külsố környezetük felé orientálódnak. Elképzelése szerint egy adott személynél a két orientációból csak az egyik érvényes, azaz a belsố és külsô orientáció ugyanazon elméleti dimenzió két végpontja. A két identitásorientáció mérésére Sampson kérdőivet is készített. A két skála korrelációs elemzését késôbb Cheek és Briggs (1982) végezte el, akik a kapott gyenge pozitív korrelációs érték alapján úgy gondolták, hogy a két orientáció két, egymástól független dimenziót jelent (Cheek, 1989). Az Identitásaspektusok Kérdőív (Aspects of Identity Questionnaire, AIQ, Cheek és Briggs, 1982) kutatássorozatunkban is alkalmazott negyedik változata (AIQ-IV, Cheek, Smith es Tropp, 2002; Cheek és Tropp, 2003) a Sampson kérdốvére alapuló, több lépésben történt fejlesztés után már négy identitásorientációt mér: a személyes és társas (újabb tanulmányukban: nyilvános - Cheek és Cheek, 2018) mellett a kollektív és kapcsolati orientációt is. Elôbbinél a csoporttagság szerepe és értéke, utóbbinál pedig a közeli kapcsolatok fontossága lényeges az önmeghatározásban. Cheek és Cheek (2018) a kérdôívvel végzett kutatásaikkal összefüggésben az identitás/énfogalom négydimenziós modelljét állították fel. A modellben az énfogalom egyik része a független én (ez jelenti a személyes ént), a másik pedig a kölcsönösen függố én, amely a kapcsolati, a nyilvános és a kollektív énbôl áll. Saját vizsgálatunkban a helyidentitás-orientáció mérésének keretéül mind a négy identitásaspektus önmeghatározásban való fontosságát mérô AIQ-IV kérdốivet választottuk. E kérdőív helyidentitásra vonatkozó tételekkel kiegészített, magyar mintán is megfelelôen mérô változatának kidolgozása szükséges elôfeltétele mind a helyidentitás-orientáció mérésének, mind a helyidentitás-orientáció és a kérdôívben szereplô egyéb orientációk közötti kapcsolat késôbbi vizsgálatának.

\section{Helyidentitás}

A hely és az identitás kétféle módon kapcsolódhat (Twigger-Ross és Uzzell, 1996). Az egyik a helyazonosulás, amely egy, egyének vagy csoport által közösen használt hely (pl. iskola) által definiált társas kategorizációt jelent („radnótisok”). A hely és identitás összetettebb kapcsolódása a helyidentitás, amelyben nagy hangsúlyt kap az identitás pszichológiai konstruktuma. A helyidentitás mind a viselkedésszabályozásban, mind a személy-környezet összeillés megteremtésében és fennmaradásában (Proshansky, Fabian és Kaminoff, 1983), mind pedig az én érzésének fenntartásában (Twigger-Ross és Uzzell, 1996) szerepet játszik. A helyidentitás az identitás önálló, dinamikus, állandóan fejlôdô, a helyekkel való tranzakció során, az aktuálisan lezajló észlelési és/ vagy kognitív folyamatokban kialakuló alstruktúrája (Proshansky, 1978; Twigger-Ross és Uzzell, 1996). Proshansky szerint a helyidentitás úgy írható le, mint specifikus fizikai környezetekrôl alkotott emlékek, fogalmak, értelmezések, elképzelések és azokhoz kapcsolódó érzések elegye. A helyidentitás lehet egy helyhez tartozó, és lehet a különbözô helyekhez tartozó, múltbéli, jelenbéli és elképzelt kogníciók mintázata is (Dúll, 
2009) - miként maga az identitás fogalma is jelölheti az egyes összetevôket éppúgy, mint azok teljes mintázatát.

A helyidentitás kutatása és a róla való elméleti gondolkodás mély gyökerekkel bír a környezetpszichológiában, ezzel együtt bizonyos aspektusait illetôen a mai napig nincsen konszenzus a kutatók között (lásd Dúll, 2017). Kutatásunk szempontjából ezen elméleti és kutatási területek közül elsôsorban a helyidentitás és egyéb identitáselemek közötti kapcsolat és a helyidentitás más, a személy-hely kapcsolatot leíró fogalmakkal való viszonya érdemel figyelmet.

A helyidentitás társas identitással való kapcsolatát már Proshansky is leírta, ám a köztük lévô viszonyt pontosan nem definiálta. Bernardo és Palma-Oliveira (2013) egyértelmúbb viszonyt fogalmazott meg, mivel szerintük a helyidentitás a társas identitás alstruktúrájának tekinthetô. Hinds és Sparks (2008) úgy gondolta ugyanakkor, hogy olyan környezeti identitás is kialakítható, amelynek csekély társas vonatkozása van. Más kutatók (pl. Twigger-Ross, Bonaiuto és Breakwell, 2003) már a személyes identitással is expliciten kapcsolatba hozzák a helyidentitást: szerintük a helyekkel történő azonosulás nyomán születố helyidentitások tartalmazzák az énnek mind a személyes, mind a társas aspektusait, Knez és Eliasson (2017) a helyidentitás, illetve a személyes és társas identitás kölcsönös viszonyát írja le: mind a személyes és a kollektív (társas) identitás tartalmaz helyekkel kapcsolatos aspektusokat, mind pedig a helyidentitás is lehet személyes vagy kollektív jellegú, Du, Litteljohn és Lennon (2013) pedig fizikai, kronológiai és szociális helyidentitásról ír. Végül más kutatók nem csak a személyes és társas identitással kapcsolják össze a helyeket: pl. Twigger-Ross és Uzzell (1996) szerint az identitás minden aspektusa rendelkezik több-kevesebb hellyel kapcsolatos vonatkozással, Hauge (2007) integratív modelljében pedig az identitásrendszer vertikális elhelyezkedésú kategóriáival (mint a nem vagy a társadalmi osztály) szemben a helyidentitás horizontális, minden vertikális dimenzión áthaladó dimenzió, azaz minden identitáselem tartalmaz helyekkel kapcsolatos aspektusokat. Mindezekhez az identitásorientációkat célunk szerint megfelelôen mérô, jelen tanulmányban tárgyalt kérdôívünk nyomán azok kapcsolatát feltáró, illetve a helyidentitás aspektusainak mérését célzó, tervezett és már zajló további kutatásaink izgalmas eredményekkel járulhatnak majd hozzá.

A helyidentitás és egyéb, a személy-hely kapcsolatot leíró fogalmak ${ }^{3}$ viszonya tisztázatlan (Manzo, 2003; Hernández, Hidalgo, Salazar-Laplace és Hess, 2007; Rollero és De Piccoli, 2010; Dúll, 2017). Kutatásunk szempontjából a legszélesebb irodalommal bíró helykötődéssel (Dúll, 2002, 2009) - az egyének és a számukra fontos helyek közötti érzelmi köteléket jellemzó fogalommal - való kapcsolat a lényeges. Egyes kutatók (pl. Brown és Werner, 1985) szerint (1) a két fogalom ugyanaz a konstruktum. Mások szerint a helykötôdés a helyidentitás (2a) része, így pl. Korpela (1989) leírásában a helyidentitás definíciójának magja a helyekhez való érzelmi kötôdés. Lalli (1992) szerint az általános kötôdés egyike a városhoz kapcsolódó identitás öt dimenziójának (a többi négy: külsố értékelés [összehasonlítás], a személyes múlttal való folytonosság, a családiasság észlelése és az elkötelezettség). Droseltis és Vignoles (2010) kutatásában a hellyel kialakított érzelmi kötôdés egyike a helyidentitás feltételezett négy dimenzi-

A helykötődés mellett ilyen fogalom többek között a helyérzék (Hummon, 1992; Jorgensen és Stedman, 2001) és a helyfüggôség (Stokols és Shumaker, 1981). 
ójának (a többi három: énkiterjesztés, környezetbe illeszkedés és hely-én hasonlóság). Más kutatók a helykötôdést a helyidentitás (2b) elôzményének írják le. Így pl. Hernández és munkatársai (2007) azt találták, hogy a két fogalom (három különbözô léptékú helyen - egy szigeten, az azt magába foglaló városban és a környéken - vizsgálva) hasonlóan viselkedik ott születettek, és különbözóképpen nem ott születettek esetében, aminek oka véleményük szerint, hogy a helykötôdés hamarabb kialakul, mint a helyidentitás. Knez (2014) értelmezésében pedig elôbb az érzelmi kapcsolat jön létre egy hellyel, és csak ezt követi a kognitív kapocs kiépülése. Ezzel szemben egyes kutatók úgy vélik, hogy ez fordítottan igaz, azaz (3) a helyidentitás része a helykötôdésnek. Így pl. Williams és Roggenbuck (1989) szerint a természeti helyekhez füzôdô helykötôdés olyan kapcsolati fogalmat jelent, amely mind funkcionális (helyfüggóség), mind érzelmi/szimbolikus jelentést és kötődést (helyidentitás) magában foglal, Kyle, Graefe és Manning (2005) szerint a helykötôdés három dimenziója különböztethetô meg, ezek egyike a helyidentitás (a másik kettô a helyfüggôség és a társas kapcsolat dimenzió). E harmadik vonulatba tartozik Hinds és Sparks (2008) vizsgálata is, amelyben a természeti környezettel kialakított érzelmi kapcsolatok jó előrejelzói voltak az elkötelezett környezeti viselkedésnek (ami többek között magában foglalja a természeti környezetben végzett tevékenységek keresését és a környezetvédô megnyilvánulásokat), azonban a környezeti identitás nem jelentett külön előrejelzô tényezôt. Végül vannak kutatók, akik a helyidentitást és a helykötôdést (4) egy magasabb rendú fogalom részének tekintik, így Jorgensen és Stedman (2001) szerint a helykötôdés, a helyidentitás és a helyfüggôség egy általánosabb kategória, az attitúdként értelmezett helyérzék speciális, affektív, kognitív és konatív dimenzióinak tekinthetô (bár az utóbbi igazolása eredményeik szerint problematikusabbnak mutatkozott). Hummon (1992) szerint pedig a helykötôdés és a helyidentitás kettô a helyérzék hat változatából (a többi négy: elégedettség a hellyel, bensôségesség, helytudatosság és közösségi képzet). A helyidentitás és helykötôdés viszonya kutatássorozatunk szempontjából azért lényeges, mivel a fenti elképzelések közül vizsgálatunk Proshansky (1978) eredeti definícióját alapul véve abba a vonulatba illeszkedik, amely szerint a helykötődés a helyidentitás része, illetve elôzménye. Ennek megfelelően a helyidentitás-orientáció mérését célzó saját kérdőívtételeink közé olyan tételek is kerültek, amelyek a helyekkel kialakított érzelmi kapcsolatra (megfogalmazás szintjén a kötôdésre, illetve a helyekkel kialakított erôs érzelmi szálakra) vonatkoznak, kutatásunknak ugyanakkor nem célja a két fogalom általunk elfogadott viszonyának igazolása.

Kutatássorozatunk szempontjából fontosak a következó szempontok. (1) A fent tárgyalt fogalmi nehézségek egyik forrása az is lehet, hogy nagyon eltérô konstruktumokhoz való viszonyulást vizsgálnak a kutatások. (2) A korábbi vizsgálatok a helyidentitást vagy annak valamely fent említett aspektusát legnagyobbrészt azt célzottan elóhívó helyzetben, konkrét helyek (pl. egy bizonyos város[rész], egy adott természeti hely vagy a vizsgálati személyek által megnevezhetố kedvenc helyek) kapcsán kutatták, vagy általánosságban, az elkötelezett, környezettudatos viselkedés kapcsán igyekeztek azt feltárni. Kutatásainkban egy, a mások által végzett vizsgálatokban nem alkalmazott megközelítés szerint célunknak és a személyiségpszichológiai nézôpontnak megfelelôen a helyidentitást általánosságban, konkrét helyeket nem megnevezve, a személyiség szintjén, az identitás/énfogalom más aspektusaival együtt vizsgáljuk. 
A helyidentitás személyiség szintjén, jelen esetben identitásorientációként történô vizsgálata elméleti és gyakorlati haszonnal is bír. Egyfelól segíthet pontosítani a helyidentitás helyét az identitásstruktúrában, hozzájárulhat a helyidentitás fogalmának mélyebb, illetve árnyaltabb megértéséhez (pl. az egyéb identitás-összetevookkel való kapcsolatának feltárása által). Amennyiben pedig fel tudjuk mérni, hogy egy személy számára önmaga meghatározásában mennyire fontosak a helyek és az azokkal kialakított kapcsolatok (fóként, ha az emögött álló aspektusokat is ismerjük), nagyobb esélylyel kaphatunk választ a gyakorlatban a személy-környezet kapcsolat minôségét, hibáit, ezek okait, vagy a helyekkel való kapcsolat megváltozásának nehézségeit és ezek kezelési sikerességét célzó, alapvetôen környezetpszichológiai kérdésekre. Mindez azért is fontos, hiszen számos kutatás eredménye mutatta ki a helyekkel való kapcsolat minôsége és a pszichológiai jóllét összefüggését (pl. Wiles, Allen, Palmer, Hayman, Keeling és Kerse, 2009; Phillips, Cheng, Yeh és Siu, 2010; Knez és Eliasson, 2017).

\section{HIPOTÉZISEK}

Kutatásunk egy hosszabb vizsgálatsorozat második lépése, amely az elsô lépéshez (Berze és Dúll, 2018) hasonlóan keresztmetszeti vizsgálat és egy, a helyidentitás-orientációt, továbbá a személyes, a társas/nyilvános, a kollektív és a kapcsolati identitásorientációkat magyar nyelven megfelelően mérô kérdőív kidolgozását célozza. Jelen vizsgálatban tehát azt feltételeztük, hogy az elsố kutatásban kialakított, és magyar egyetemista mintán felvett kérdőíven az ott született eredmények alapján alkalmazott változtatások elérik céljukat, így sikerült egy olyan kérdôívet létrehozni, amely a teljes felnốtt (tehát nem csupán egyetemista) mintán megfelelôen méri mind a helyidentitást mint identitásorientációt - azaz a személyek közötti egyéni különbséget abban, hogy a számukra jelentôs helyeket és azokhoz fúzôdô kapcsolatukat mennyire tartják fontosnak önmaguk meghatározásában -, mind pedig az eredeti angol nyelvú kérdôívben szereplố fent említett identitásorientációkat.

\section{MÓDSZER}

A módosított kérdôívet célunk eléréséhez két változatban vettük fel online módon, felnôtt mintán, kényelmi mintavételt alkalmazva. A kutatást az ELTE PPK Kutatásetikai Bizottsága engedélyezte (az engedély száma: 2018/453).

A tanulmányban a kérdôív alapvetô jellemzésén túl nem részletezzük a jelen kutatásban is használt kérdôív elôzố kutatási szakaszban történt kialakítási lépéseit (lásd Berze és Dúll, 2018), kiindulópontunk a kérdôív elốzô kutatásban használt második változata, amelyet abban a kutatásban már nem módosítottunk. A kérdôívre jelen kutatási lépésben vonatkozó dokumentációt a kérdôív e kutatásban használt két változata szerint strukturáljuk. 


\section{A kérdốiv e kutatásban használt elsố változata}

Vizsgálatsorozatunkban a szakirodalmi áttekintésben említett Aspects of Identity Questionnaire negyedik változatát (AIQ-IV, Cheek és mtsai, 2002) használjuk fel, amely a skálák és tételek leírásával együtt angol nyelven szabadon hozzáférhetô, ${ }^{4}$ és amelyet saját tételekkel egészítettünk ki. Az eredeti kérdōív 45 kérdést tartalmaz. A leírás nem tartalmazza az eredeti kérdőív pszichometriai jellemzőinek bemutatását. A kérdôív kitöltésekor a válaszadó ötfokú Likert-skálán döntheti el, hogy az adott tételt mennyire érzi fontosnak önmaga meghatározásában. Az angol nyelvú kérdôív négy skála (négy identitásorientáció) mérését célozza, azaz mennyire fontosak a személy számára önmaga meghatározásában a

1. személyes aspektusok (10 kérdés): belsô jellemzôk (értékek, gondolatok, érzések, célok), az énjérôl alkotott nézetei, folytonosság és egyediség érzete;

2. kapcsolati aspektusok (10 kérdés): közeli kapcsolatok (barátság, párkapcsolat) minôsége és a személy ezekben betöltött szerepe;

3. társas aspektusok (7 kérdés): szociális szerepek, ahogyan ôt mások látják, és ahogyan gondolkodnak róla;

4. kollektív aspektusok (8 kérdés): a (nem választott) csoporttagság (család, etnikum, vallás/felekezet, nemzet, anyanyelv) szerepe és értéke,

és tartalmaz továbbá 10, a fenti négy skálába nem tartozó tételt is. A kutatás elsố lépésében ezen a struktúrán nem változtattunk, csupán a tételek lefordítása után a megfelelô módszertani megfontolások figyelembevételével (lásd Berze és Dúll, 2019) kilenc magyar nyelvú, a szakirodalom alapján kialakított, helyidentitásra vonatkozó tétellel egészítettük ki. Ezen tételeket az eredeti tételek közé elszórva illesztettük be. A módszernek a kérdôív integritását befolyásoló hatását egy külön változat felvételével mértük, amelynek eredménye nem jelzett jelentôs negatív hatást az eredeti kérdôív integritására.

Elsôként a kutatássorozatunk elsô lépésében használt második (akkor tovább nem módosított) tesztváltozat 9 helyidentitásra vonatkozó tételén jelen kutatásban végrehajtott változásokat tekintjük át. Az említett második változat faktorelemzése során a helyidentitásra vonatkozó tételek faktora az elsố lett a struktúrában. Ezt több tényezô is okozhatta, például az, hogy a magyar nyelven megfogalmazott tételek összetartozása magasabb, mint a lefordított, ezáltal bizonyos mértékú jelentésváltozáson átesô tételeké, vagy összefügghetett az alacsony megmagyarázott varianciával, de lehetett oka az is, hogy minden tételbe a „helyek” megnevezés került ${ }^{5}$, mivel a helyidentitást általánosan, a személyiség szintjén mértük, és így nem akartunk konkrét helyeket (pl. otthon, munkahely stb.) megnevezni. Emellett két-két tétel esetében magas volt a korrelációs érték, ami azt mutatta, ezek a tételek nem differenciálnak megfelelően (a kitöltôk hasonlónak értelmezték ôket). E két okból a 9 tételból 7 tétel szövegezését több tekintetben is megváltoztattuk: (1) a „hely” megnevezés helyébe 2 tétel esetében a „fizikai környezet”, egy (a jelentés ${ }^{6}$ fontosságát hangsúlyozó) tételnél pedig a „környezeti

www.midss.org/sites/default/files/aiq.pdf (Letöltve: 2020. 06. 24.)

Pl. „Számomra jelentôs helyekhez fưzôdô kapcsolatom” - ezt a tételt jelen kutatásban módosítottuk.

A hely (place, lásd Canter, 1977) a jelentéssel felruházott tér (space). 
tér" került; (2) a helyidentitás szakirodalomban szereplô tényezôi közül explicitebb formában beemeltük a kérdések témái közé a környezeti preferenciát, ${ }^{8}$ és (3) az eredetileg nem specifikus aspektusra vonatkozó tétel helyébe az énkiterjesztést ${ }^{9}$ (amikor a személy a részének érzi az adott helyet: vö. Droseltis és Vignoles, 2010) illesztettük. Mindezekkel együtt 4 tételt áthelyeztünk, egyrészt a más orientációkat mérô tételek közti egyenletesebb eloszlás érdekében, másrészt pedig azért, hogy csökkentsük a beillesztés hatását a helyidentitásra vonatkozó tétel mögötti más skálához tartozó, az elôzô kutatási lépésben nem megfelelô faktorba került tételre (így kettôt egy-egy skálába nem tartozó tétel elé helyeztünk).

A módosítások ugyanakkor érintették az eredeti angol nyelvú kérdôív lefordított tételeit is. Egyfelól a korábbi kutatási lépésben a nem megfelelô faktorba kerülô tételek megfogalmazásán módosítottunk úgy, hogy az eredeti angol nyelvú szövegezésnek és tartalomnak továbbra is megfeleljen. A módosítás lehetett csupán egy-egy szó átfogalmazása, ${ }^{10}$ ám a kollektív tételek esetében markánsabb módosítás is előfordult (lásd alább). Egy angol lektor bevonásával áttekintettük a fordítást, és néhány, egyébként jól múködô kapcsolati tételben is javítottunk egy-egy szót, ${ }^{11}$ vagy egy bizonyos angol nyelvi szerkezet fordítását egy árnyalattal pontosabbra fogalmaztuk. Mivel a helyidentitás az egész élet folyamán, és nem csupán az eredeti angol nyelvú kérdőívet kitöltô egyetemista mintában meglévô és hatással bíró fogalom, így e második kutatási lépésben nem csupán egyetemista mintán kívántuk felvenni a kérdôívet. A 10 skálán kívüli tétel közül 5 tételt is egyfelôl az alkalmazni kívánt minta miatt ${ }^{12}$ töröltünk, másrészt viszont törlésükkel célunk volt az elsố lépésben mutatkozó, a társadalomtudományi kutatásokban elvárható értéktôl $(60 \%)$ jócskán elmaradó mértékú megmagyarázott variancia növelése. Külön említenünk szükséges a kollektív orientációt mérô skálát, amelynek tartalmában a legnagyobb eltérés mutatkozott az eredeti és a három magyar nyelvú változat között, aminek okát valószínúleg a szociokulturális különbségek adják. A kérdôív szüloohazájára, az Egyesült Államokra jellemzô megfogalmazások és témák (pl. a hazájára büszke polgár, a politikai tevékenység, az akcentus, vagy akár az etnikai háttér, a vallási és politikai színezetû community kifejezés) esetében az előzô kutatási lépésben már alkalmaztunk módosításokat, ami javított is a faktortartalmon, ám a skála így sem lett teljes. Így a kollektív skálába tartozó tételek közül 9 tételen módosítottunk a hazai szociokulturális jellemzóknek megfelelôen, így került be pl. a rassz és etnikum szerepét célzó tételbe a „földrajzi-tájegységi hovatartozás”, a vallást célzó tétel szövege így bôvült „vallási közösséghez tartozással”, a hazához tartozást célzó tételbe is így került be a vélhetôen szélesebb körben elfogadhatónak gondolt „állampolgárság”. A kol-

\footnotetext{
$7 \quad$ Pl. „Bizonyos fizikai környezetek rám gyakorolt hatása”, illetve „Amit bizonyos környezeti terek jelentenek számomra”.

8 „Preferenciám egyes helyek, vagy helyek bizonyos jellemzôi iránt.”

9 „Hogy részemnek érzek egy-egy természeti vagy épített környezeti helyet.”

10 Pl. a 9-es tétel: a „reményeim” szót „várakozásaim”-ra cseréltük, hogy jobban kifejezze az élettel kapcsolatos személyes terveket: „Személyes céljaim és várakozásaim a jövőre nézve.”

11 Pl. a 41-es tételben az „intimate” szó fordítását „meghitt”-rôl „bizalmas”-ra módosítottuk: „Bizalmas kapocs egy-egy másik személlyel.”

12 Ilyen tétel pl. az eredetileg a szakmaválasztásra, az egyetemi, fôiskolai szerepre és a tanulmányi teljesítményre vonatkozó tétel.
} 
lektív skála helyeket említô tétele, amely a helyek közösségi vonatkozását célozza, de az elôzô kutatási lépés második tesztváltozatában bekerült a helyidentitás faktorába, az eredeti alkotói szándékot jobban hangsúlyozó átfogalmazáson esett át, és kikerült belôle a „hely” szó, ám továbbra is utalt a helyekre az „ahol” szóval. ${ }^{13}$ A skálák tartalmát (utalva az elôzô kutatási lépésben használt kérdốiv skálatartalmaira is) az 1. táblázatban mutatjuk be.

1. táblázat. Skálatartalmak az eredeti kérdốívben, valamint az elsố és a jelen kutatási lépésben használt kérdôívváltozatok esetén

\begin{tabular}{|c|c|c|c|}
\hline Skálák & $\begin{array}{l}\text { eredeti angol nyelvú } \\
\text { eredeti kérdóív }\end{array}$ & $\begin{array}{c}\text { tételsorszámok } \\
\text { a korábbi kutatási } \\
\text { lépésben } \\
\text { (helyekre vonatkozó } \\
\text { tételek beillesztése } \\
\text { után) }\end{array}$ & $\begin{array}{l}\text { tételsorszámok } \\
\text { a jelen kutatásban }\end{array}$ \\
\hline személyes & $\begin{array}{l}2,5,8,11,14,18,21 \\
25,27,32\end{array}$ & $\begin{array}{l}2,5,9,12,15,20,24, \\
28,31,37\end{array}$ & $\begin{array}{l}2,5,9,12,15,20,23, \\
28,31,36\end{array}$ \\
\hline kapcsolati & $\begin{array}{l}22,26,28,31,34,35 \\
37,39,41,43\end{array}$ & $\begin{array}{l}25,29,32,36,39,41 \\
43,46,49,51\end{array}$ & $\begin{array}{l}24,29,32,35,38,39, \\
41,43,45,47\end{array}$ \\
\hline társas & $3,6,9,12,15,17,20$ & $3,6,10,13,16,19,23$ & $\begin{array}{l}3,6,10,13,16,19, \\
22\end{array}$ \\
\hline kollektív & $\begin{array}{l}4,7,10,13,24,29, \\
38,42\end{array}$ & \begin{tabular}{|l}
$4,7,11,14,27,33$, \\
44,50
\end{tabular} & \begin{tabular}{|l}
$4,8,11,14,27,33$, \\
42,46
\end{tabular} \\
\hline helyidentitás & $\varnothing$ & $\begin{array}{l}8,18,21,30,35,40, \\
45,48,53\end{array}$ & $\begin{array}{l}7,17,21,25,30,34, \\
40,44,48\end{array}$ \\
\hline skálán kívüli tételek & $\begin{array}{l}1,16,19,23,30,33, \\
36,40,44,45\end{array}$ & $\begin{array}{l}1,17,22,26,34,38 \\
42,47,52,54\end{array}$ & $1,18,26,37,49$ \\
\hline
\end{tabular}

A kérdôív így elkészült változatát az ELTE Pedagógiai és Pszichológiai Kara által biztosított Qualtrics felhôalapú szoftver (Qualtrics, Provo, UT) segítségével online töltötték ki a résztvevôk. A kérdốí linkjére kattintva az elsố oldalon a kitöltốk elolvashatták a tájékoztatót, majd az ebben foglaltak ismeretében, mindezekhez hozzájárulva kezdhették meg a kérdőív kitöltését az „Igen” lehetőségre kattintva (a „Nem” válaszra kattintással a program a kérdốiv utolsó, a részvételt megköszönô oldalára ugrott). A kitöltés önkéntes (a hozzájárulásnál választható volt „Nem” opció is) és anonim volt (a Qualtricsban azt a beállítást alkalmaztuk, hogy a program ne tárolja a kitöltéskor használt eszköz vagy hálózat elektronikus azonosítóját vagy elérési útvonalát), a kitöltést vállaló résztvevốk ösztönzô jutalomban nem részesültek. Az elsô változat esetében 210 db kitöltésnél lezártuk a kitöltési lehetôséget, ezek közül 177 db volt használható, 33 db kérdôív adatait idô elôtti befejezés miatt nem használtuk fel. A 177 kitöltôbôl 134 nô, 43 férfi, az életkoruk átlaga: 47,63 év, szórása: 12,531, az alsó életkor: 23 év, a felsô életkor: 79 év volt.

A kérdôív kitöltésével kapott adatokon az ott kapott eredményekkel történô öszszevethetôség érdekében az előzô kutatási lépés metódusával megegyezôen az SPSS

13 „Helyek, ahol most élek vagy ahol felnôttem” helyett „Akik között és ahol élek, vagy felnôttem”. 
program 26.0 verziójának (IBM Corp., 2019) segítségével itemanalízist, reliabilitásvizsgálatot, majd az adatok alkalmasságának tesztelése után feltáró faktoranalízist (EFA) végeztünk (lásd Eredmények). A feltáró faktorelemzés során principal axis factoring becslési módszert használtunk, az 1-nél nagyobb sajátértékú (azaz egy változónál több információt hordozó) faktorokat vizsgáltuk, legfeljebb 25 iterációt engedtünk meg, a faktorsúlyok közül csak a jelentést hordozó 0,3 felettieket ${ }^{14}$ tartottuk meg. A faktorstruktúra és stabilitásának teljesebb elemzése érdekében a faktorok forgatásához a faktorok függetlenségét megôrző derékszögú (Varimax) és azok korrelációját megengedô ferde (Promax) forgatást is alkalmaztunk, mivel a helyidentitás identitásstruktúrában elfoglalt helye vitatott, ugyanakkor sok kutató szerint számos identitásaspektussal öszszefügg, továbbá ez utóbbiak maguk is kapcsolatban vannak a szakirodalom alapján. Az általunk beillesztett, helyidentitásra vonatkozó tételeken külön reliabilitásvizsgálatot és itemanalízist, valamint eloszlásvizsgálatot készítettünk.

\section{A kérdốv e kutatásban használt második változata}

A kérdôív fentebb tárgyalt elsô változatának eredményein elvégzett feltáró faktoranalízis alapján szükségesnek találtuk néhány, kizárólag a személyes és a kollektív skálába tartozó tétel átfogalmazását és így egy második változat elkészítését. Tíz - 6 személyes és 4 kollektív skálába tartozó - tétel szövegezésében történt módosítás. A személyes skála tételei esetén történô átfogalmazások során ügyeltünk arra, hogy az eredeti angol nyelvú megfogalmazáshoz és tartalomhoz húek maradjunk, sốt egy esetben az átfogalmazás épp az egyetemista minta visszajelzései alapján a számukra megfelelóbb formában módosított tétel eredeti változatát jobban közelítô megváltoztatását jelentette. ${ }^{15}$ A kollektív skála tételei az elsố változatban is markánsabb módosításokat tartalmaztak, a 14. tétel esetében most még jobban hangsúlyoztuk az adott helyen található közösségeket (így az „ahol” szó is kikerült belôle). ${ }^{16}$ A helyidentitásra vonatkozó tételek közül egyiken sem módosítottunk.

A kérdơív így elkészült változatát az ELTE PPK által biztosított Qualtrics felhôalapú szoftver (Qualtrics, Provo, UT) segítségével az elsố változattal egyezô módon és feltételek mellett online töltötték ki a résztvevôk. A második változat esetében $504 \mathrm{db}$ kitöltésnél lezártuk a kitöltési lehetôséget, ezek közül 432 db volt használható, 72 db kérdőív adatait idô előtti befejezés miatt töröltük. A 432 kitöltôbôl 335 nô, 97 férfi, életkoruk átlaga: 42,06 év, szórása: 11,786, az alsó életkor: 18 év, a felsô életkor: 82 év volt. A link kiküldésekor, illetve meghirdetésekor felhívtuk az érdeklôdôk figyelmét arra, hogy ha nemrégiben kitöltött ilyen kérdôívet, ne tegye meg újra, azaz igyekez-

\footnotetext{
14 Bár az elsô kutatási lépésben a 0,35-nél nagyobb faktorsúlyú tételeket tartottuk meg az elemzésben, a minta (tervezett) nagysága miatt Hair, Black, Babin és Anderson (2010, 115) táblázata alapján e kutatásunkban a 0,3 felettiek megtartása mellett döntöttünk. Ezzel a jelenlegi és a korábbi lépés eredményeinek összehasonlíthatósága az ott kapott eredmények alapján nem sérült.

A 20. tételbe visszakerült a „félelem” és a „szorongás” kezelése, amelyeket az egyetemista kitöltôk visszajelzései (nehezen találták érvényesnek magukra/mindenkire) alapján vettünk ki a tétel szövegébôl: „Ahogyan saját rosszkedvemet, illetve félelmeimet vagy szorongásaimat kezelem.”

16 „A közösség(ek), amely(ek)ben élek, vagy amely(ek)ben nevelkedtem.”
} 
tünk elérni, hogy a kérdôív ezen változatát ne az elsố változatot ismerô résztvevôk töltsék ki.

A kérdőív ezen változatának kitöltésével kapott adatokon az SPSS program 26.0 verziójának (IBM Corp., 2019) segítségével az elsô változatnál leírt (és ezzel az elôzô kutatási lépéssel megegyezô és így összehasonlíthatóságot biztosító módon) statisztikai számításokat (a helyidentitás-tételek esetében külön is), valamint az ott leírt módon feltáró faktoranalízist végeztünk. Ezt kiegészítettük az MPlus program 8-as verziójával (Muthén és Muthén, 1998-2017) elvégzett feltáró faktoranalízissel (EFA) is. Ezen, mint látni fogjuk, az eredeti kérdôívhez közelebb álló faktorstruktúrájú változat esetében az eredeti amerikai kérdôív faktorstruktúrájához való illeszkedés ellenôrzéséhez az MPlus program 8-as verziójával készítettünk strukturális egyenlet modellezésen (SEM) alapuló konfirmatív faktorelemzést (CFA) (lásd Eredmények). Mindkét MPlus-elemzés esetében robusztus maximum likelihood becslést (MLR) alkalmaztunk.

\section{EREDMÉNYEK}

\section{Statisztikai mutatók}

A kérdőív felnôtt mintán felvett két változatának statisztikai mutatói alapján mind a két változat (1) megbízható (Cronbach $\alpha$ értéke: I. 0,927; II: 0,910), (2) látszatérvényessége (face validity) az elsố változat lefordított tételeinek külsố megítélôi és a kitöltôk visszajelzései alapján megfelelô, továbbá egy már létezô, érvényes kérdôív tételein alapulnak, az elsố két változatban az új tételek pedig a vonatkozó szakirodalom alapján kerültek kialakításra, (3) itemszerkezete megfelelô: a Cronbach $\alpha$ értéke csak egy-egy tétel (I: 1.; II: 11.) kiemelése esetén volna egy-egy ezreddel magasabb.

A kérdő́iv mindhárom változatának kitöltésével nyert adatok alkalmasak faktoranalízisre: (1) KMO értéke: I: 0,847; II: 0,883; (2) Bartlett-teszt szignifikáns: p < 0,01; (3) Anti-image mátrix: minden érték $0,5<$. Az elemszám $(n=177 ; 432)$ az elsố változat esetében az esetleges további módosítások szükségességének feltárási célzatával elegendônek (a faktorsúlyok átlagosan magasak, továbbá az eredeti amerikai kérdôívet 199 fố egyetemistával vették fel: lásd Cheek és mtsai, 2002), a második változat esetében pedig mindenképpen ${ }^{17}$ megfelelőnek tekinthetô a faktoranalízis elvégzéséhez.

\section{A helyekre vonatkozó tételek}

A faktoranalízis során a helyidentitást célzó 9 új tétel mindegyike egy - ám a korábbi kutatási lépésben kapott eredménnyel szemben nem az elsô, hanem a második - faktorba került mindkét változatban. Ennek nyomán külön skálaként kezelhetôk, amely-

\footnotetext{
17 A legtöbb kutató (idézi ôket MacCallum, Widaman, Zhang és Hong, 1999) iránymutatását figyelembe véve: Guilford (1954) szerint 200, Cattell (1978) szerint 250 a faktoranalízishez szükséges minimális elemszám, Comrey és Lee (1992) a 300-as elemszámot már jónak tekinti, Gorsuch (1983) szerint a változószám ötszöröse a megfelelố elemszám.
} 
nek megbízhatósága magas (Cronbach $\alpha=0,9$, illetve 0,887). Az itemanalízis egyik itemnél sem jelez problémát (a Cronbach $\alpha$ értéke bármely item kiemelése esetén alacsonyabb volna, mint a jelen érték). Az itemek közötti korrelációk mindegyike szignifikáns $(\mathrm{p}<0,01)$, a Spearman korrelációs együtthatók értéke 0,288 és 0,712, illetve 0,210 és 0,698 között mozog. A skálán elért összpontszámok átlaga 30,45, illetve 30,32, szórása 6,361, illetve 6,128, a kitöltốk összpontszámai a 9-tôl 45-ig terjedô skálán 13 és 44 pont, illetve 10 és 45 pont között mozogtak.

\section{Faktorstruktúrák}

Az SPSS programban elvégzett feltáró faktoranalízis során az előzó kutatási lépéssel megegyezó módon Varimax és Promax rotációt is alkalmaztunk mind a két változat (I és II) esetében. Mindkét esetben 11 darab 1-nél nagyobb sajátértékú faktort kaptunk, amelyek közül a könyökszabályt (Scree-tesztet) alkalmazva 6 faktorban maximalizáltuk az elemzésben értelmezett faktorok számát.

Mindkét változatra igaz, hogy a ferde Promax forgatás eredményei a faktorok tartalmát tekintve lényegesen nem térnek el a Varimax rotáció eredményeitôl (az egyes faktorokat tekintve nincs eltérés, vagy faktoronként csupán egy-egy tételben tér el a két tartalmi struktúra - a faktortöltések különböznek), az elemzésben értelmezett faktorok közötti korreláció nem magas: a korrelációs együtthatók értéke I: 0,046 és 0,410; II: 0,071 és 0,429 közötti. Az értelmezésben elsôsorban a Promax rotáció (mintázat mátrixának) eredményeit vettük figyelembe.

A második változat MPlusban végzett feltáró faktoranalízise során a többféle forgatási eredmény összehasonlításához és az illeszkedési mutatók kinyeréséhez a program által alapértelmezett Geomin ferde forgatást alkalmaztuk. A faktorok sajátértékét, a Scree-plotot és az illeszkedési mutatókat figyelembe véve egy 7 faktoros megoldást találtunk értelmezhetônek. Az illeszkedési mutatók ${ }^{18}$ alapján $\left(\chi^{2}[854]=1620,87\right.$, $\mathrm{p}<0,001, \mathrm{RMSEA}=0,046[0,042-0,049], \mathrm{CFit}=0,985, \mathrm{CFI}=0,898, \mathrm{SRMR}=0,031) \mathrm{ez}$ a modell viszonylag jól illeszkedik.

A második változat adatain a strukturális egyenlet modellezésen alapuló konfirmatív faktoranalízist is végeztünk. Elméleti modellként az eredeti amerikai kérdôív teljes faktorstruktúráját tekintettük, kiegészítve a feltáró elemzések során kapott helyidentitás faktorral (ugyanis már a korábbi kutatási lépésben is láttuk, hogy a helyidentitás tételek egy faktorba rendeződnek). A teljes amerikai faktorstruktúrával való összevetés során nem kaptunk igazán jó illeszkedést, a CFI értéke elmarad a jó illeszkedést jelentô értéktôl $\left(\chi^{2}[886]=1696,61, p<0,001\right.$, RMSEA = 0,046 [0,043-0,049], CFit = 0,977, $\mathrm{CFI}=0,874, \mathrm{SRMR}=0,073)$. Kiegészítésként elvégeztük a konfirmatív elemzést a nem jól múködô kollektív tételek kihagyásával. Ebben az esetben az összes mutató jó illesz-

\footnotetext{
18 Az RMSEA esetében a 0,05 alatti érték kitûnô, a 0,05 és 0,08 közötti érték pedig megfelelô illeszkedést mutat, az RMSEA értékének 0,05-ös értéktôl való szignifikáns eltérését a Cfit értéke jelzi: nem szignifikáns ( $\mathrm{p}>0,05)$ CFit érték jelez elfogadható illeszkedést (Browne és Cudek, 1993). A CFI esetében 0,9 feletti értéket várunk (Brown, 2006), míg az SRMR esetében 0,08 alatti érték jelez jó illeszkedést (Kline, 2005).
} 
kedést jelölt $\left(\chi^{2}[584]=1095,46, p<0,001\right.$, RMSEA $=0,045[0,041-0,049]$, CFit $=0,978$, $\mathrm{CFI}=0,903$, SRMR $=0,063)$.

A magyarázott variancia értékei, bár az elsô kutatási lépésben használt változatok esetében mutatkozó értékeknél magasabbak, mindkét változat esetében alacsonyak: az 1-nél nagyobb sajátértékú faktorok esetén I: 56,055\%, illetve II: 49,768\%; a maximalizált számú faktorok esetén I: 47,872\%, illetve II: 43,494\%.

A létrejött faktorstruktúrákat az elsô változat esetében a 2. és 3., a második esetében a 4., 5., 6. és 7. táblázatban foglaltuk össze.

2. táblázat. A kérdôív elsố változatának adatain végzett feltáró faktoranalízis (SPSS) eredménye az elemzésben értelmezett faktorokat tekintve

\begin{tabular}{|l|c|c|c|c|c|c|}
\hline \multicolumn{7}{|c|}{ Varimax forgatással } \\
\hline Tételek* & \multicolumn{7}{|c|}{ Faktorok } \\
\hline & F1 & F2 & F3 & F4 & F5 & F6 \\
\hline K41 &, 711 & & & & & \\
\hline K38 &, 689 & & & & & \\
\hline K45 &, 683 & & & & & \\
\hline K39 &, 682 & & & & & \\
\hline K43 &, 646 & & & & & \\
\hline K47 &, 641 & & & & & \\
\hline K35 &, 624 & & & & & \\
\hline K32 &, 540 & & & & & \\
\hline K24 &, 536 & & & &, 334 & \\
\hline K29 &, 484 & & & & & \\
\hline H34 & &, 810 & & & & \\
\hline H21 & &, 803 & & & & \\
\hline H30 & &, 798 & & & & \\
\hline H48 & &, 719 & & & & \\
\hline H7 & &, 697 & & & & \\
\hline H44 & &, 624 & & & & \\
\hline H25 & &, 595 & & & & \\
\hline H40 & &, 513 & & & & \\
\hline H17 & &, 497 & & & & \\
\hline T13 & & &, 761 & & & \\
\hline T19 & & &, 738 & & & \\
\hline T6 & & &, 700 & & & \\
\hline T16 & & &, 694 & & & \\
\hline T3 & & &, 561 & & & \\
\hline T10 & & &, 539 & & &, 352 \\
\hline T22 & & &, 459 & & & \\
\hline C8 & & & &, 678 & & \\
\hline C33 & & & &, 608 & & \\
\hline C46 & &, 348 & &, 582 & & \\
\hline X37 & & & &, 579 & & \\
\hline C11 & & & &, 546 & & \\
\hline & & & & \\
\hline
\end{tabular}

\begin{tabular}{|l|c|c|c|c|c|c|}
\hline \multicolumn{7}{|c|}{ Promax forgatással } \\
\hline Tételek* & \multicolumn{7}{|c|}{ Faktorok } \\
\hline & F1 & F2 & F3 & F4 & F5 & F6 \\
\hline K41 &, 756 & & & & & \\
\hline K38 &, 753 & & & & & \\
\hline K45 &, 717 & & & & & \\
\hline K39 &, 713 & & & & & \\
\hline K35 &, 653 & & & & & \\
\hline K43 &, 610 & & & & & \\
\hline K47 &, 544 & & & & & \\
\hline K32 &, 435 & & & & & \\
\hline K24 &, 421 & & & & & \\
\hline H34 & &, 839 & & & & \\
\hline H30 & &, 818 & & & & \\
\hline H21 & &, 809 & & & & \\
\hline H48 & &, 728 & & & & \\
\hline H7 & &, 721 & & & & \\
\hline H44 & &, 652 & & & & \\
\hline H25 & &, 632 & & & & \\
\hline H17 & &, 524 & & & & \\
\hline H40 & &, 500 & & & & \\
\hline T13 & & &, 792 & & & \\
\hline T19 & & &, 752 & & & \\
\hline T6 & & &, 718 & & & \\
\hline T16 & & &, 717 & & & \\
\hline T3 & & &, 610 & & & \\
\hline T10 & & &, 479 & & &, 325 \\
\hline T22 & & &, 438 & & & \\
\hline C8 & & & &, 645 & & \\
\hline C33 & & & &, 564 & & \\
\hline C46 & & & &, 555 & & \\
\hline C11 & & & &, 526 & & \\
\hline X37 & & & &, 522 & & \\
\hline C42 & & & &, 522 & & \\
\hline & & & & \\
\hline
\end{tabular}




\begin{tabular}{|l|c|c|c|c|c|c|}
\hline \multicolumn{7}{|c|}{ Varimax forgatással } \\
\hline Tételek* & \multicolumn{7}{|c|}{ Faktorok } \\
\hline & F1 & F2 & F3 & F4 & F5 & F6 \\
\hline X49 & & & &, 545 & & \\
\hline C42 & & & &, 508 & & \\
\hline S36 & & & & &, 677 & \\
\hline S31 & & & & &, 619 & \\
\hline S15 & & & & &, 534 &, 311 \\
\hline S20 &, 353 & & & &, 493 & \\
\hline S2 & & & & &, 449 & \\
\hline S5 & & & & & &, 596 \\
\hline S12 & & & & & &, 594 \\
\hline S9 & & & & & &, 580 \\
\hline S23 & & & & & &, 349 \\
\hline
\end{tabular}

\begin{tabular}{|l|c|c|c|c|c|c|}
\hline \multicolumn{7}{|c|}{ Varimax forgatással } \\
\hline Tételek* $^{*}$ & F1 & F2 & F3 & F4 & F5 & F6 \\
\hline & & & &, 503 & & \\
\hline X49 & & & & &, 765 & \\
\hline S36 & & & & &, 602 & \\
\hline S31 & & & & &, 459 & \\
\hline S15 & & & &, 432 & \\
\hline S20 & & & & &, 419 & \\
\hline S2 & & & & & &, 669 \\
\hline S5 & & & & & &, 632 \\
\hline S12 & & & & & &, 582 \\
\hline S9 & & & & & & \\
\hline & & & & & & \\
\hline & & & & & & \\
\hline
\end{tabular}

* betûk: eredetileg melyik skála tétele: S - személyes, T - társas, C - kollektív, $\mathrm{K}$ - kapcsolati, X - skálán kívüli

\begin{tabular}{|l|c|c|c|c|c|}
\hline \multicolumn{6}{|c|}{ Faktorok közötti korrelációk (Promax) } \\
\hline & F1 & F2 & F3 & F4 & F5 \\
\hline F2 &, 373 & & & & \\
\hline F3 &, 378 &, 345 & & & \\
\hline F4 &, 046 &, 239 &, 170 & & \\
\hline F5 &, 410 &, 108 &, 238 &, 108 & \\
\hline F6 &, 391 &, 286 &, 324 &, 068 &, 388 \\
\hline
\end{tabular}

Az elsố változat feltáró elemzéssel született faktorstruktúráiban a faktorok tartalmát tekintve a derékszögú és ferde rotáció utáni eredmények közötti különbség elenyészô: az elsô és a hatodik faktor esetében 1-1 tétel hiányzik a Promax rotáció esetében a Varimax forgatáshoz képest.

A faktorstruktúra, bár az elôzô kutatási lépés második tesztváltozatának eredményéhez képest pontosabb faktortartalmi egyezést mutatott az eredeti kérdôív skáláival, egyik rotációt alkalmazva sem fedte pontosan az eredeti kérdôív skáláit: a kapcsolati skála - a derékszögú forgatás esetében maradéktalanul, a ferde szögú rotáció esetében a 29. tétel híján - teljes lett, a társas faktorba minden tétel bekerült, ugyanakkor a személyes orientáció tételei két külön faktorba kerültek - Varimax forgatás esetében egy (a 28.), Promax rotációnál két (a 23. és a 28.) tétel híján, amelyek mindkét esetben különálló faktort alkottak (a struktúramátrixban ezzel együtt mindkét esetben szerepelnek az adott faktorban). Az elôzoó kutatási lépés eredményeihez hasonlóan, ugyanakkor annál ezen skála esetében is jobb egyezéssel, a kollektív orientáció skálája mutatta a leggyengébb eredményt, hiszen e faktornál három tétel is hiányzott az eredeti skálatartalomból, és két skálán kívüli tétel is bekerült. Ugyanakkor a faktor egyértelmúen címkézhetô közösségiként (haza, nyelv, etnikum, illetve földrajzi-tájegységi hovatartozás - amely a helyre vonatkozás mellett sem került a helyekre vonatkozó tételeket tartalmazó faktorba -, vallás és politika). Mindezekkel együtt egy olyan tétel sem volt, amely más faktorba került volna, mint az eredeti angol nyelvú kérdôívben. 
3. táblázat. A kérdôív elsô változatának adatain végzett feltáró faktoranalízis (SPSS) eredménye az eredeti skálákhoz viszonyítva

\begin{tabular}{|l|l|l|}
\hline Faktorok & Varimax forgatással & Promax forgatással \\
\hline 1. faktor & a kapcsolati orientáció összes tétele & $\begin{array}{l}\text { a kapcsolati orientáció tételei, } \\
\text { egy különbséggel: } \\
\text {-: K29 (str. mátrixban korrelál) }\end{array}$ \\
\hline 2. faktor & a helyidentitásra vonatkozó összes tétel & mint Varimax \\
\hline 3. faktor & társas orientáció összes tétele & mint Varimax \\
\hline $\begin{array}{l}\text { 4. faktor } \\
\text { a kollektív orientáció tételei } \\
\text {-: C4, C14, C27 } \\
\text { +: X37, X49 }\end{array}$ & mint Varimax \\
\hline $\begin{array}{l}\text { 5. faktor } \\
\text {-: S5, S9, S12, S23, S28 }\end{array}$ & mint Varimax \\
\hline $\begin{array}{l}\text { 6. faktor } \\
\text { S5, S9, S12, S23 }\end{array}$ & $\begin{array}{l}\text { mint Varimax, egy különbséggel: } \\
\text {-: S23 (str. mátrixban korrelál) }\end{array}$ \\
\hline $\begin{array}{l}\text { nem került } \\
\text { a fenti } \\
\text { faktorokba }\end{array}$ & C4, C14, C27, S28 & mint Varimax, továbbá S23, K29 \\
\hline
\end{tabular}

Magyarázat: -: hiányzik az eredeti angol nyelvú kérdôív feltüntetett skálájából; +: többlet az eredeti angol nyelvú kérdôív feltüntetett skálájának tételeihez képest; aláhúzva: második faktorsúllyal szerepel a faktorban; betúk: eredetileg melyik skála tétele: S - személyes, T - társas, C - kollektív, K - kapcsolati.

A tételszámok már a helyekre vonatkozó tételek beillesztése következtében módosult új sorszámokat jelentik.

4. táblázat. A kérdôív második változatának adatain végzett feltáró faktoranalízis (SPSS) eredménye az elemzésben értelmezett faktorokat tekintve

\begin{tabular}{|l|c|c|c|c|c|c|}
\hline \multicolumn{7}{|c|}{ Varimax forgatással } \\
\hline Tételek* & \multicolumn{7}{|c|}{ Faktorok } \\
\hline & F1 & F2 & F3 & F4 & F5 & F6 \\
\hline K39 &, 764 & & & & & \\
\hline K38 &, 716 & & & & & \\
\hline K45 &, 699 & & & & & \\
\hline K41 &, 695 & & & & & \\
\hline K47 &, 644 & & & & & \\
\hline K29 &, 631 & & & & & \\
\hline K43 &, 622 & & & & & \\
\hline K24 &, 603 & & & & & \\
\hline K35 &, 586 & & & & & \\
\hline K32 &, 560 & & & & & \\
\hline H21 & &, 808 & & & & \\
\hline H30 & &, 757 & & & & \\
\hline H34 & &, 751 & & & & \\
\hline H48 & &, 724 & & & & \\
\hline H7 & &, 704 & & & & \\
\hline
\end{tabular}

\begin{tabular}{|l|l|l|l|l|l|l|}
\hline \multicolumn{7}{|c|}{ Promax forgatással } \\
\hline Tételek* & \multicolumn{7}{|c|}{ Faktorok } \\
\hline & F1 & F2 & F3 & F4 & F5 & F6 \\
\hline K39 &, 830 & & & & & \\
\hline K38 &, 765 & & & & & \\
\hline K45 &, 744 & & & & & \\
\hline K41 &, 674 & & & & & \\
\hline K35 &, 642 & & & & & \\
\hline K47 &, 626 & & & & & \\
\hline K29 &, 607 & & & & & \\
\hline K43 &, 579 & & & & & \\
\hline K24 &, 551 & & & & & \\
\hline K32 &, 459 & & & & & \\
\hline H21 & &, 872 & & & & \\
\hline H30 & &, 778 & & & & \\
\hline H34 & &, 764 & & & & \\
\hline H7 & &, 752 & & & & \\
\hline H48 & &, 725 & & & & \\
\hline
\end{tabular}




\begin{tabular}{|l|l|l|l|l|l|l|}
\hline \multicolumn{7}{|c|}{ Varimax forgatással } \\
\hline Tételek* & \multicolumn{5}{|c|}{ Faktorok } \\
\hline & F1 & F2 & F3 & F4 & F5 & F6 \\
\hline H44 & &, 679 & & & & \\
\hline H40 & &, 539 & & & &, 326 \\
\hline H17 & &, 511 & & & & \\
\hline H25 & &, 452 & & & & \\
\hline T13 & & &, 825 & & & \\
\hline T3 & & &, 733 & & & \\
\hline T16 & & &, 720 & & & \\
\hline T6 & & &, 713 & & & \\
\hline T19 & & &, 632 & & & \\
\hline T22 & & &, 388 & & & \\
\hline T10 & & &, 351 & & & \\
\hline S36 & & & &, 643 & & \\
\hline S31 &, 301 & & &, 623 & & \\
\hline S15 & & & &, 573 & & \\
\hline S9 & & & &, 547 & & \\
\hline S23 & & & &, 512 & & \\
\hline S12 & & & &, 420 & & \\
\hline S5 & & & &, 413 & & \\
\hline S20 & & & &, 405 & & \\
\hline S28 & & & &, 344 & & \\
\hline S2 & & & &, 340 & & \\
\hline C33 & & & & &, 772 & \\
\hline C46 & & & & &, 697 & \\
\hline C8 & & & & &, 658 & \\
\hline C11 & & & & &, 430 & \\
\hline C42 & & & & &, 404 & \\
\hline X18 & & &, 339 & &, 367 & \\
\hline X49 & & & & &, 353 &, 640 \\
\hline X37 & & & & &, 348 &, 622 \\
\hline
\end{tabular}

\begin{tabular}{|l|l|l|l|l|l|l|}
\hline \multicolumn{7}{|c|}{ Promax forgatással } \\
\hline Tételek* & \multicolumn{5}{|c|}{ Faktorok } \\
\hline & F1 & F2 & F3 & F4 & F5 & F6 \\
\hline H44 & &, 659 & & & & \\
\hline H17 & &, 527 & & & & \\
\hline H40 & &, 503 & & & & \\
\hline H25 & &, 387 & & & & \\
\hline T13 & & &, 830 & & & \\
\hline T6 & & &, 736 & & & \\
\hline T16 & & &, 710 & & & \\
\hline T3 & & &, 708 & & & \\
\hline T19 & & &, 622 & & & \\
\hline T22 & & &, 347 & & & \\
\hline S36 & & & &, 688 & & \\
\hline S31 & & & &, 662 & & \\
\hline S15 & & & &, 657 & & \\
\hline S9 & & & &, 590 & & \\
\hline S23 & & & &, 569 & & \\
\hline S12 & & & &, 381 & & \\
\hline S20 & & & &, 360 & & \\
\hline S2 & & & &, 328 & & \\
\hline S28 & & & &, 321 & & \\
\hline C33 & & & & &, 848 & \\
\hline C46 & & & & &, 660 & \\
\hline C8 & & & & &, 633 & \\
\hline C11 & & & & &, 335 &, 303 \\
\hline C42 & & & & &, 333 & \\
\hline X49 & & & & & &, 690 \\
\hline X37 & & & & & &, 643 \\
\hline & & & & & & \\
\hline & & & & & & \\
\hline & & & & & \\
\hline
\end{tabular}

* betúk: eredetileg melyik skála tétele: $\mathrm{S}$ - személyes, $\mathrm{T}$ - társas, $\mathrm{C}$ - kollektív, $\mathrm{K}$ - kapcsolati, X - skálán kívüli

\begin{tabular}{|l|c|c|c|c|c|}
\hline \multicolumn{6}{|c|}{ Faktorok közötti korrelációk (Promax) } \\
\hline & F1 & F2 & F3 & F4 & F5 \\
\hline F2 &, 241 & & & & \\
\hline F3 &, 278 &, 169 & & & \\
\hline F4 &, 429 &, 276 &, 301 & & \\
\hline F5 &, 148 &, 358 &, 071 &, 138 & \\
\hline F6 &, 311 &, 274 &, 133 &, 270 &, 358 \\
\hline
\end{tabular}


A feltáró analízis eredményei alapján módosított tételeket tartalmazó második változat SPSS programmal készült faktorstruktúráiban is csupán 3 (az 5., 10. és 18., a legutolsó egy eredeti skálán kívüli) tétel esetében van különbség a ferde és a derékszögú forgatás által létrejött faktortartalmak között, azaz csak eggyel több tétel esetében, mint az elsố változat eredményében.

Az SPSS programmal készült faktorstruktúra - bár egyik rotációt alkalmazva sem fedte pontosan az eredeti kérdốiv skáláit - e kutatási lépés elsô kérdôíváltozatáéval összehasonlítva pontosabbá vált: a kapcsolati orientáció skálája mindkét forgatás esetében teljes lett, a társas orientáció skálája esetében csak Promax rotáció esetében hiányzik a 10. tétel (de a struktúramátrixban szerepel), a személyes orientáció tételei egy faktorba kerültek, és Varimax forgatás esetében a faktor teljes, Promax rotáció esetében hiányzik az 5. tétel (de a struktúramátrixban szerepel). Elmondható tehát, hogy az elsố változat tételei módosításainak szükségességét a fenti vonatkozó eredmények nagy részben igazolják. A kollektív orientáció faktorból az elsô változattal megegyezó három tétel hiányzik, amelyek itt együtt kerültek egy külön (az elemzésbe nem vont 7.) faktorba, ám az elsố változathoz képest Varimax rotáció esetében csak egy skálán kívüli tétel került be a faktorba, Promax forgatás esetében ez sem.

5. táblázat. A kérdôív második változatának adatain az MPlus programban végzett feltáró faktoranalízis eredménye

\begin{tabular}{|l|c|r|r|r|r|r|r|}
\hline Tételek & F1 & F2 & F3 & F4 & F5 & F6 & F7 \\
\hline T13 & $\mathbf{0 , 8 5 0}$ & $-0,081$ & $-0,073$ & 0,066 & $-0,005$ & $-0,007$ & 0,040 \\
\hline T3 & $\mathbf{0 , 7 5 6}$ & $-0,017$ & 0,009 & 0,031 & $-0,057$ & $-0,030$ & 0,002 \\
\hline T6 & $\mathbf{0 , 7 4 6}$ & 0,004 & 0,000 & 0,051 & 0,016 & $-0,094$ & $-0,084$ \\
\hline T16 & $\mathbf{0 , 6 9 1}$ & 0,088 & 0,084 & 0,002 & $-0,001$ & 0,064 & $-0,044$ \\
\hline T19 & $\mathbf{0 , 5 9 6}$ & 0,070 & $-0,024$ & $\mathbf{0 , 1 6 1}$ & $-0,015$ & 0,080 & $-0,034$ \\
\hline T22 & $\mathbf{0 , 3 4 9}$ & $-0,025$ & $\mathbf{0 , 2 0 7}$ & 0,103 & 0,049 & $-0,077$ & 0,060 \\
\hline T10 & $\mathbf{0 , 3 1 3}$ & $-0,042$ & $\mathbf{0 , 2 9 8}$ & $-0,081$ & $-0,001$ & 0,184 & 0,109 \\
\hline H21 & $-0,003$ & $\mathbf{0 , 8 3 4}$ & 0,020 & $-0,031$ & 0,043 & $-0,157$ & $-0,018$ \\
\hline H30 & $-0,016$ & $\mathbf{0 , 7 8 7}$ & $-0,017$ & 0,008 & 0,069 & $-0,020$ & $-0,081$ \\
\hline H34 & $-0,028$ & $\mathbf{0 , 7 4 9}$ & $-0,032$ & $-0,016$ & 0,067 & $-0,048$ & 0,134 \\
\hline H7 & 0,080 & $\mathbf{0 , 7 3 0}$ & 0,043 & $-0,115$ & 0,016 & $-0,162$ & 0,021 \\
\hline H48 & 0,014 & $\mathbf{0 , 7 1 6}$ & $-0,064$ & 0,093 & $-0,053$ & 0,142 & 0,195 \\
\hline H44 & $-0,065$ & $\mathbf{0 , 6 7 6}$ & 0,011 & 0,058 & $-0,019$ & $\mathbf{0 , 3 9 9}$ & 0,010 \\
\hline H17 & $\mathbf{0 , 1 8 3}$ & $\mathbf{0 , 5 0 4}$ & 0,077 & $-0,025$ & $-0,055$ & 0,068 & $-0,018$ \\
\hline H40 & 0,008 & $\mathbf{0 , 5 0 0}$ & $-0,010$ & 0,152 & $-0,009$ & $\mathbf{0 , 4 8 0}$ & 0,067 \\
\hline H25 & $-0,017$ & $\mathbf{0 , 4 4 1}$ & 0,096 & 0,094 & 0,031 & 0,002 & $-0,026$ \\
\hline S36 & $-0,030$ & $-0,050$ & $\mathbf{0 , 6 8 0}$ & 0,117 & $-0,051$ & 0,006 & 0,111 \\
\hline S31 & $-0,026$ & 0,008 & $\mathbf{0 , 6 4 6}$ & 0,149 & $-0,024$ & $-0,062$ & 0,007 \\
\hline S15 & 0,015 & 0,028 & $\mathbf{0 , 5 8 6}$ & 0,031 & $-0,015$ & $-0,107$ & 0,041 \\
\hline S9 & 0,052 & $-0,011$ & $\mathbf{0 , 5 6 3}$ & 0,001 & $-0,036$ & 0,056 & $-0,027$ \\
\hline S23 & 0,032 & $-0,064$ & $\mathbf{0 , 5 1 3}$ & $-0,121$ & 0,015 & 0,132 & 0,042 \\
\hline S5 & 0,022 & 0,108 & $\mathbf{0 , 4 2 8}$ & $-0,020$ & $-0,113$ & 0,100 & $-0,033$ \\
\hline S12 & 0,094 & $\mathbf{0 , 1 1 0}$ & $\mathbf{0 , 4 1 2}$ & 0,127 & 0,068 & $-0,042$ & $-0,128$ \\
\hline
\end{tabular}




\begin{tabular}{|l|c|c|c|c|c|c|c|}
\hline Tételek* & F1 & F2 & F3 & F4 & F5 & F6 & F7 \\
\hline S20 & 0,065 & $\mathbf{0 , 1 2 4}$ & $\mathbf{0 , 3 7 3}$ & 0,092 & 0,063 & 0,067 & $-0,094$ \\
\hline S2 & $-0,064$ & 0,008 & $\mathbf{0 , 3 5 2}$ & 0,003 & 0,149 & $-0,122$ & $-0,230$ \\
\hline S28 & $\mathbf{- 0 , 2 2 9}$ & 0,021 & $\mathbf{0 , 3 4 6}$ & 0,164 & 0,241 & $-0,019$ & $-0,020$ \\
\hline K39 & 0,077 & $-0,051$ & $-0,038$ & $\mathbf{0 , 7 9 2}$ & $-0,036$ & 0,052 & 0,030 \\
\hline K45 & 0,067 & 0,042 & 0,033 & $\mathbf{0 , 7 2 2}$ & $-0,090$ & 0,020 & 0,081 \\
\hline K38 & 0,045 & $\mathbf{- 0 , 1 3 0}$ & 0,076 & $\mathbf{0 , 6 8 9}$ & 0,076 & 0,037 & $-0,002$ \\
\hline K41 & 0,021 & $-0,023$ & 0,060 & $\mathbf{0 , 6 8 4}$ & 0,039 & 0,038 & $-0,036$ \\
\hline K47 & $-0,036$ & 0,050 & 0,038 & $\mathbf{0 , 6 4 5}$ & 0,119 & 0,003 & 0,089 \\
\hline K29 & $-0,002$ & 0,020 & 0,098 & $\mathbf{0 , 6 0 3}$ & 0,017 & $-0,014$ & $-0,072$ \\
\hline K35 & $\mathbf{0 , 1 9 1}$ & 0,037 & $-0,044$ & $\mathbf{0 , 6 0 1}$ & $-0,003$ & $-0,084$ & 0,064 \\
\hline K43 & $-0,037$ & 0,036 & 0,066 & $\mathbf{0 , 5 8 5}$ & $-0,016$ & 0,006 & $-\mathbf{0 , 2 5 4}$ \\
\hline K24 & 0,061 & 0,036 & 0,046 & $\mathbf{0 , 5 8 2}$ & 0,056 & 0,005 & $-0,099$ \\
\hline K32 & $-0,070$ & 0,012 & $\mathbf{0 , 2 2 7}$ & $\mathbf{0 , 4 6 7}$ & 0,030 & 0,091 & $-0,228$ \\
\hline C27 & $\mathbf{0 , 2 0 1}$ & 0,001 & $-0,020$ & $\mathbf{0 , 3 0 5}$ & 0,310 & $-0,098$ & $-0,023$ \\
\hline X49 & 0,032 & 0,003 & 0,021 & $-0,062$ & $\mathbf{0 , 6 7 0}$ & $\mathbf{0 , 4 0 6}$ & $-0,060$ \\
\hline X37 & 0,006 & $-0,053$ & $-0,022$ & 0,110 & $\mathbf{0 , 6 3 4}$ & $\mathbf{0 , 4 7 1}$ & $-0,035$ \\
\hline C33 & $-0,068$ & 0,104 & $-0,037$ & 0,050 & 0,592 & 0,001 & 0,328 \\
\hline C11 & $-0,053$ & $-0,069$ & $-0,059$ & 0,047 & $\mathbf{0 , 5 6 3}$ & $-0,001$ & 0,071 \\
\hline C8 & 0,064 & 0,098 & 0,031 & $-0,069$ & $\mathbf{0 , 5 5 8}$ & 0,001 & 0,349 \\
\hline C4 & $-0,001$ & $-0,026$ & $-0,032$ & 0,248 & 0,352 & $-0,043$ & $-0,070$ \\
\hline C14 & $\mathbf{0 , 2 5 7}$ & 0,025 & $-0,008$ & 0,242 & 0,346 & $-0,176$ & 0,015 \\
\hline C42 & 0,058 & 0,000 & 0,099 & $-0,044$ & 0,335 & $-0,025$ & $\mathbf{0 , 2 7 7}$ \\
\hline X26 & $\mathbf{0 , 2 2 2}$ & 0,074 & 0,128 & $-0,142$ & 0,287 & $\mathbf{0 , 2 5 2}$ & 0,153 \\
\hline C46 & $-0,094$ & 0,025 & 0,010 & $\mathbf{0 , 1 5 7}$ & 0,523 & $-0,009$ & $\mathbf{0 , 5 3 1}$ \\
\hline X18 & $\mathbf{0 , 3 3 2}$ & 0,007 & 0,049 & $-0,069$ & 0,219 & 0,066 & $\mathbf{0 , 3 7 1}$ \\
\hline X1 & $\mathbf{0 , 1 8 8}$ & $\mathbf{0 , 2 8 1}$ & 0,030 & $-0,146$ & 0,093 & 0,066 & $-0,140$ \\
\hline
\end{tabular}

* betük: eredetileg melyik skála tétele: S - személyes, T - társas, C - kollektív, K - kapcsolati, X - skálán kívüli Vastaggal szedve: szignifikáns faktorsúlyok, szürke háttér: az adott tétel legnagyobb és 0,3-nál nagyobb faktorsúlya, dólttel szedve: bár itt nem szignifikáns, de a struktúramátrix szerint a faktorba tölt

Az MPlus programban végzett feltáró faktoranalízis eredménye azt mutatja, hogy a kollektív orientáció tételein kívül a többi eredeti tétel mind a megfelelô skálába rendezôdött, e skálák tartalma megfelel az eredeti amerikai kérdôív skálatartalmainak. A kollektív skála esetében elófordulnak nem szignifikáns faktortöltések (a 4., 14., 33. és 42. tétel esetében, bár a struktúramátrix szerint ebbe a faktorba töltenek), illetve két (a 27. és a 46.) tétel más faktorba került.

A második változat faktorstruktúrája a strukturális egyenlet modellezés konfirmatív elemzésének eredménye alapján még nem mutat igazán jó illeszkedést az eredeti amerikai kérdő́iv faktorszerkezetével. Ebben bizonyára szerepet játszik az, hogy a kollektív orientáció tételei, bár a tételmódosítások ezek esetében sem maradtak hatás nélkül, nem múködnek még megfelelôen (a legtöbb alacsony faktortöltés ebben a faktorban található). Fontos azt is megjegyezni, hogy a hibakovarianciák alapján a konfirmatív faktorelemzés eredménye alapján 6 pár tétel magasabb fokú együtt járást mutat, ezeket a kitöltök hasonlónak értelmezték. Ezen tételpárok közül 4 az 
6. táblázat. A kérdôív második változatának adatain végzett feltáró faktoranalízis (SPSS és MPlus) eredménye az eredeti skálákhoz viszonyítva

\begin{tabular}{|c|c|c|c|}
\hline Faktorok & SPSS: Varimax forgatással & SPSS: Promax forgatással & $\begin{array}{l}\text { MPlus: Geomin } \\
\text { forgatással }\end{array}$ \\
\hline 1. faktor & \multicolumn{2}{|c|}{ a kapcsolati orientáció összes tétele } & $\begin{array}{l}\text { a társas orientáció összes } \\
\text { tétele }\end{array}$ \\
\hline 2. faktor & \multicolumn{2}{|c|}{ a helyidentitásra vonatkozó összes tétel } & $\begin{array}{l}\text { a helyidentitásra } \\
\text { vonatkozó összes tétel }\end{array}$ \\
\hline 3. faktor & $\begin{array}{l}\text { a társas orientáció összes } \\
\text { tétele }\end{array}$ & $\begin{array}{l}\text { társas orientáció tételei } \\
\text {-: T10 (str. mátrixban } \\
\text { korrelál) }\end{array}$ & $\begin{array}{l}\text { a személyes orientáció } \\
\text { összes tétele }\end{array}$ \\
\hline 4. faktor & $\begin{array}{l}\text { a személyes orientáció } \\
\text { összes tétele }\end{array}$ & $\begin{array}{l}\text { a személyes orientáció } \\
\text { tételei } \\
-: \underline{S 5} \text { (str. mátrixban } \\
\text { korrelál) }\end{array}$ & $\begin{array}{l}\text { a kapcsolati orientáció } \\
\text { összes tétele } \\
\text { +: C27 }\end{array}$ \\
\hline 5. faktor & $\begin{array}{l}\text { a kollektív orientáció } \\
\text { tételei } \\
\text {-: C4, C14, C27 (külön } \\
\text { faktorban együtt) } \\
\text { +: X18 }\end{array}$ & $\begin{array}{l}\operatorname{mint} \text { Varimax, de X18 } \\
\text { nincs benne }\end{array}$ & $\begin{array}{l}\text { a kollektív orientáció } \\
\text { tételei } \\
\text {-: C4, C14, C33, C42 (str. } \\
\text { mátrix szerint a faktorba } \\
\text { tölt), C27, C46 } \\
\text { +: X37, X49 }\end{array}$ \\
\hline 6. faktor & \multicolumn{2}{|l|}{$\begin{array}{l}\text { két skálán kívüli: X37, X49 } \\
\text { „szexualitás” }\end{array}$} & $\begin{array}{l}\text { csak másodlagos } \\
\text { faktortöltések } \\
\end{array}$ \\
\hline 7. faktor & - & - & $\begin{array}{l}\text { a kollektív skálából a C46 } \\
\text { és egy skálán kívüli (X18) }\end{array}$ \\
\hline $\begin{array}{l}\text { nem került } \\
\text { a fenti } \\
\text { faktorokba }\end{array}$ & $\mathrm{C} 4, \mathrm{C} 14, \mathrm{C} 27$ & $\mathrm{C} 4, \mathrm{~S} 5, \mathrm{~T} 10, \mathrm{C} 14, \mathrm{C} 27$ & C4, C14, C33, C42 \\
\hline
\end{tabular}

Magyarázat: -: hiányzik az eredeti angol nyelvú kérdőív feltüntetett skálájából; +: többlet az eredeti angol nyelvú kérdôív feltüntetett skálájának tételeihez képest; aláhúzva: második faktorsúllyal szerepel a faktorban; betûk: eredetileg melyik skála tétele: S - személyes, T - társas, C - kollektív, K - kapcsolati, X - skálán kívüli.

A tételszámok már a helyekre vonatkozó tételek beillesztése következtében módosult új sorszámokat jelentik.

eredeti kérdő́ivben is szerepel. Az MPlus programban végzett EFA faktorstruktúrájának 6., elsôdleges faktortöltést nem tartalmazó faktorában két ilyen helyidentitásra vonatkozó tétel is szerepel, ezek javítása a faktorstruktúra stabilitásának javulásához is hozzájárulhat. Az összes tételre kiterjedó SEM CFA eredménye alapján a helyidentitás-orientációt mérô faktornak a többi orientációt célzó faktorral mért korrelációs értékei csökkenô sorrendben a következók: kollektív: 0,485, személyes: 0,327, kapcsolati: 0,248, társas: 0,181. Bár az SPSS-elemzés alapján a kollektív identitásorientáció mérését célzó skála így is használható, ám az ebbe a skálába tartozó tételek további pontosítása lényeges az egyes identitásorientációk és a helyidentitás-orientáció összefüggéseinek feltárásához.

Összegzésképpen a kérdőív eddigi két kutatási lépésében használt különböző változatainak feltáró faktoranalízisében kapott eredményeket, illetve a SEM CFA illeszkedési mutatóit a 8. táblázatban foglaltuk össze. 
7. táblázat. A kérdôív második változatának adatain végzett SEM CFA eredménye: a teljes eredeti amerikai faktorstruktúrával összevetve, a helyidentitás tételekkel kiegészítve

\begin{tabular}{|c|c|c|c|c|c|}
\hline \multicolumn{6}{|c|}{ Tételek* } \\
\hline & F1 & F2 & F3 & F4 & F5 \\
\hline S2 & ,360 & & & & \\
\hline $\mathrm{S} 5$ & 450 & & & & \\
\hline S9 & ,573 & & & & \\
\hline S12 &, 592 & & & & \\
\hline S15 & ,598 & & & & \\
\hline S20 & 519 & & & & \\
\hline S23 & ,425 & & & & \\
\hline S28 & ,416 & & & & \\
\hline S31 & ,631 & & & & \\
\hline S36 & ,618 & & & & \\
\hline K24 & &, 657 & & & \\
\hline K29 & & ,671 & & & \\
\hline K32 & & ,587 & & & \\
\hline K35 & & ,624 & & & \\
\hline K38 & & ,708 & & & \\
\hline K39 & &, 740 & & & \\
\hline K41 & & ,736 & & & \\
\hline K43 & & 626 & & & \\
\hline $\mathrm{K} 45$ & & ,724 & & & \\
\hline K47 & & ,688 & & & \\
\hline T3 & & & ,752 & & \\
\hline $\mathrm{T} 6$ & & & ,735 & & \\
\hline $\mathrm{T} 10$ & & & \begin{tabular}{|l|}
, 396 \\
\end{tabular} & & \\
\hline T13 & & & ,822 & & \\
\hline T16 & & & ,740 & & \\
\hline T19 & & & ,663 & & \\
\hline T22 & & &, 444 & & \\
\hline $\mathrm{C} 4$ & & & & ,362 & \\
\hline $\mathrm{C} 8$ & & & & ,709 & \\
\hline C11 & & & & 474 & \\
\hline C14 & & & & ,398 & \\
\hline C27 & & & & ,351 & \\
\hline C33 & & & & ,771 & \\
\hline C42 & & & & ,419 & \\
\hline C46 & & & & ,761 & \\
\hline $\mathrm{H} 7$ & & & & & ,687 \\
\hline H17 & & & & & ,532 \\
\hline H21 & & & & & ,808 \\
\hline $\mathrm{H} 25$ & & & & & ,506 \\
\hline H30 & & & & & \begin{tabular}{|l|}
, 794 \\
\end{tabular} \\
\hline H34 & & & & & \begin{tabular}{|l|}
, 794 \\
\end{tabular} \\
\hline $\mathrm{H} 40$ & & & & &, 536 \\
\hline $\mathrm{H} 44$ & & & & & ,662 \\
\hline $\mathrm{H} 48$ & & & & & \begin{tabular}{|l}
, 749 \\
\end{tabular} \\
\hline
\end{tabular}

\begin{tabular}{|c|c|c|c|c|c|}
\hline \multicolumn{6}{|c|}{ Faktormeghatározottság } \\
\hline & $\mathrm{F} 1$ & F2 & F3 & F4 & F5 \\
\hline & ,900 & ,947 &, 937 & ,915 & ,947 \\
\hline \multicolumn{6}{|c|}{ Korrelációk } \\
\hline & F1 & F2 & F3 & F4 & \\
\hline F2 & 561 & & & & \\
\hline F3 & ,318 & ,348 & & & \\
\hline F4 & ,241 & ,297 & ,126 & & \\
\hline F5 & ,327 & ,248 & ,181 & 485 & \\
\hline \multicolumn{6}{|c|}{ Hibakovariancia } \\
\hline 14 és 27 & ,438 & & & & \\
\hline 40 és 44 &, 421 & & & & \\
\hline 7 és 21 &, 347 & & & & \\
\hline 31 és 36 &, 345 & & & & \\
\hline 46 és 48 & 315 & & & & \\
\hline 38 és 39 & ,271 & & & & \\
\hline
\end{tabular}

* betûk: eredetileg melyik skála tétele: $\mathrm{S}$ - személyes, T - társas, C - kollektív, $\mathrm{K}$ - kapcsolati, X - skálán kívüli 
8. táblázat. Az eredeti kérdôív skáláihoz tartozó tételek faktorokban való megjelenése a kérdôív különböző változataiban feltáró analízis esetén és a SEM CFA illeszkedési mutatói (összehasonlítva a korábbi kutatási lépés 2. kérdőívváltozatának eredményeivel)

\begin{tabular}{|c|c|c|c|c|c|c|c|c|c|c|}
\hline \multirow[t]{2}{*}{ Skálák } & \multirow[t]{2}{*}{$\begin{array}{l}\text { angol nyel- } \\
\text { vû eredeti } \\
\text { kérdôív }\end{array}$} & \multirow{2}{*}{$\begin{array}{l}\text { tételsorszámok } \\
\text { a korábbi kuta- } \\
\text { tási lépésben } \\
\text { (helyekre vo- } \\
\text { natkozó tételek } \\
\text { beillesztése } \\
\text { után) }\end{array}$} & \multirow[t]{2}{*}{$\begin{array}{l}\text { tételsorszá- } \\
\text { mok a jelen } \\
\text { kutatásban }\end{array}$} & \multicolumn{2}{|c|}{$\begin{array}{l}\text { elôzö kutatási lépés } \\
\text { 2. változatának fak- } \\
\text { toranalizise után } \\
\text { (jelen kutatás tétel- } \\
\text { számaival) }\end{array}$} & \multicolumn{2}{|c|}{$\begin{array}{c}\text { 1. változat } \\
\text { faktoranalízise } \\
\text { után }\end{array}$} & \multicolumn{3}{|c|}{$\begin{array}{c}\text { 2. változat } \\
\text { faktoranalízise után }\end{array}$} \\
\hline & & & & $\begin{array}{l}\text { Varimax } \\
\text { (SPSS) }\end{array}$ & $\begin{array}{l}\text { Promax } \\
\text { (SPSS) }\end{array}$ & $\begin{array}{l}\text { Varimax } \\
\text { (SPSS) }\end{array}$ & $\begin{array}{l}\text { Promax } \\
\text { (SPSS) }\end{array}$ & $\begin{array}{l}\text { Varimax } \\
\text { (SPSS) }\end{array}$ & $\begin{array}{l}\text { Promax } \\
\text { (SPSS) }\end{array}$ & $\begin{array}{l}\text { Geomin } \\
\text { (MPlus) }\end{array}$ \\
\hline személyes & $\begin{array}{l}2,5,8,11 \\
14,18,21 \\
25,27,32\end{array}$ & $\begin{array}{l}2,5,9,12, \\
15,20,24,28, \\
31,37\end{array}$ & $\begin{array}{l}2,5,9,12, \\
15,20,23, \\
28,31,36\end{array}$ & $\begin{array}{c}\mathrm{F}: 4 . \\
-: 2,12 \\
28 \\
+: \varnothing\end{array}$ & $\begin{array}{c}F: 4 \\
-: 2,9 \\
12,28 \\
+: \emptyset\end{array}$ & $\begin{array}{l}\text { F: } 5 . \\
\text { és } 6 . \\
-: 28 \\
+: \varnothing\end{array}$ & $\begin{array}{c}\text { F: } 5 . \\
\text { és } 6 . \\
-: 23,28 \\
+: \varnothing\end{array}$ & $\begin{array}{l}\text { F: } 4 . \\
-: \varnothing \\
+: \varnothing\end{array}$ & $\begin{array}{l}\mathrm{F}: 4 . \\
-: \underline{\mathrm{S} 5} \\
+: \varnothing\end{array}$ & $\begin{array}{l}\mathrm{F}: 3 . \\
-: \varnothing \\
+: \varnothing\end{array}$ \\
\hline kapcsolati & $\begin{array}{l}22,26,28, \\
31,34,35, \\
37,39,41, \\
43\end{array}$ & $\begin{array}{l}25,29,32,36, \\
39,41,43,46, \\
49,51\end{array}$ & $\begin{array}{l}24,29,32, \\
35,38,39, \\
41,43,45, \\
47\end{array}$ & $\begin{array}{c}F: 2 . \\
-: 32, \underline{39} \\
+: \emptyset\end{array}$ & $\begin{array}{l}F: 2 . \\
-: 32 \\
39,46 \\
+: \varnothing\end{array}$ & $\begin{array}{l}\mathrm{F}: 1 . \\
-: \varnothing \\
+: \varnothing\end{array}$ & $\begin{array}{l}F: 1 . \\
-: 29 \\
+: \varnothing\end{array}$ & \multicolumn{2}{|c|}{$\begin{array}{l}\text { F: } 1 . \\
-: \varnothing \\
+: \varnothing\end{array}$} & $\begin{array}{c}\text { F: } 4 . \\
-: \varnothing \\
+: \text { C27 }\end{array}$ \\
\hline társas & $\begin{array}{l}3,6,9,12 \\
15,17,20\end{array}$ & $\begin{array}{l}3,6,10,13 \\
16,19,23\end{array}$ & $\begin{array}{l}3,6,10,13 \\
16,19,22\end{array}$ & $\begin{array}{l}F: 3 . \\
-: \emptyset \\
+: \varnothing\end{array}$ & $\begin{array}{l}F: 3 . \\
-: 22 \\
+: \varnothing\end{array}$ & \multicolumn{2}{|c|}{$\begin{array}{l}\text { F: } 3 . \\
-: \varnothing \\
+: \varnothing\end{array}$} & $\begin{array}{l}\text { F: } 3 . \\
-: \varnothing \\
+: \varnothing\end{array}$ & $\begin{array}{l}\mathrm{F}: 3 . \\
-: 10 \\
+: \varnothing\end{array}$ & $\begin{array}{l}\text { F: } 1 . \\
-: \varnothing \\
+: \varnothing\end{array}$ \\
\hline kollektív & $\begin{array}{l}4,7,10 \\
13,24,29 \\
38,42\end{array}$ & $\begin{array}{l}4,7,11,14, \\
27,33,44,50\end{array}$ & $\begin{array}{l}4,8,11, \\
14,27,33, \\
42,46\end{array}$ & $\begin{array}{c}F: 5 . \\
-: 4, \underline{11} \\
14,27 \\
+: \emptyset\end{array}$ & $\begin{array}{c}F: 5 . \\
-: 4,8 \\
11,14 \\
27 \\
+: \emptyset\end{array}$ & $\begin{array}{r}\mathrm{F}: \\
-: 4,1 \\
+:\end{array}$ & $\begin{array}{l}4 . \\
4, \underline{27} \\
\varnothing\end{array}$ & $\begin{array}{r}\mathrm{F}: \\
-: 4,1 \\
+:\end{array}$ & $\begin{array}{l}5 . \\
4,27 \\
\varnothing\end{array}$ & $\begin{array}{c}\text { F: } 5 . \\
-: 4^{*}, \\
14^{*}, \\
27,33^{*}, \\
42^{*}, 46 \\
+: 37,49\end{array}$ \\
\hline helyidentitás & $\varnothing$ & $\begin{array}{l}8,18,21,30 \\
35,40,45 \\
48,53\end{array}$ & $\begin{array}{l}7,17,21, \\
25,30,34, \\
40,44,48\end{array}$ & \multicolumn{2}{|c|}{$\begin{array}{l}F: 1 . \\
-: \emptyset \\
+: 14\end{array}$} & \multicolumn{2}{|c|}{$\begin{array}{l}\text { F: } 2 . \\
-: \varnothing \\
+: \varnothing\end{array}$} & \multicolumn{2}{|c|}{$\begin{array}{l}\text { F: } 2 . \\
-: \varnothing \\
+: \varnothing\end{array}$} & $\begin{array}{l}\text { F: } 2 . \\
-: \varnothing \\
+: \varnothing\end{array}$ \\
\hline
\end{tabular}

\begin{tabular}{|c|c|c|}
\hline $\begin{array}{l}\text { SEM CFA illeszkedési mutatók (az erede- } \\
\text { ti amerikai kérdôív struktúráját elméleti } \\
\text { alapként tekintve) }\end{array}$ & $\begin{array}{l}\text { elôzó kutatási lépés } \\
\text { 2. változatának faktoranalizise után }\end{array}$ & $\begin{array}{l}\text { jelen kutatási lépés } \\
\text { 2. változatának faktoranalízise után }\end{array}$ \\
\hline skálába tartozó összes tétel esetében & $\begin{array}{l}\chi^{2}(888)=1504,80, p<0,001, \\
R M S E A=0,047[0,043-0,051], \\
C F i t=0,877, C F I=0,848, S R M R=0,071\end{array}$ & $\begin{array}{l}\chi^{2}(886)=1696,61, \mathrm{p}<0,001, \\
\text { RMSEA }=0,046[0,043-0,049], \\
\text { CFit }=0,977, \text { CFI }=0,874, \text { SRMR }=0,073\end{array}$ \\
\hline kollektív tételek nélkül & $\begin{array}{l}\chi^{2}(585)=966,474, p<0,001 \\
R M S E A=0,046[0,040-0,051] \\
C F i t=0,921, C F I=0,888, S R M R=0,069\end{array}$ & $\begin{array}{l}\chi^{2}(584)=1095,46, \mathrm{p}<0,001, \\
\text { RMSEA }=0,045[0,041-0,049], \\
\text { CFit }=0,978, \text { CFI }=0,903, \text { SRMR }=0,063\end{array}$ \\
\hline
\end{tabular}

Magyarázat: F: faktor sorszáma; -: hiányzik az eredeti angol nyelvú kérdôív feltüntetett skálájából; +: többlet az eredeti angol nyelvú kérdôív feltüntetett skálájának tételeihez képest; aláhúzva: második faktorsúllyal ebben a faktorban is szerepel, *: a faktorstruktúra mátrixa szerint a faktorba tölt 


\section{MEGVITATÁS}

Feltételeztük, hogy a helyidentitás identitásorientációként történô vizsgálatára és mérésére a korábbi kutatási lépésben alkotott és használt kérdőívünkön végrehajtott módosítások után a helyidentitás-, illetve a többi négy (a személyes, a társas/nyilvános, a kollektív és a kapcsolati) orientációt is teljes felnôtt mintán megfelelôen mérô kérdőívet kapunk. Mint láttuk, az identitásorientációkat mérô kérdőívbe illesztve a helyidentitásra vonatkozó új tételek e kutatási lépés mindkét kérdôívváltozatában is egy faktorba rendezôdtek, és értelmezhetôknek bizonyultak. Az egyes tételek közötti szignifikáns korrelációs értékek azt igazolják, hogy azok, bár összefüggnek, és egy jelenségre vonatkoznak, nem pontosan ugyanazon részjelenségeket mérik. Ezzel együtt a magasabb korrelációs értékek és a SEM-alapú konfirmatív faktorelemzés hibakovarianciái (bár ezek az eredeti kérdőív tételei között is előfordultak) mind a kérdôív további finomításában, mind a helyidentitás aspektusait és mérésük módszertanát illetô általános megfontolások esetében fontos szemponttal szolgálnak.

A kilenc, helyre vonatkozó tételt tartalmazó skálán a kérdôív mindkét változata esetében nagyon változatos összeredmények születtek. Az eredmények alapján elmondható, hogy a teljes felnôtt mintában is markáns egyéni különbségek mutatkoztak abban, hogy a személyek számára a helyek és az azokkal kialakított pszichológiai (érzelmi és kognitív) kapcsolat milyen mértékben fontos énfogalmuk meghatározásában, tehát az eredmények ismét igazolták a helyidentitás orientációként történô értelmezésével kapcsolatos elképzelésünket.

Jelen kutatás eredményei a helyekre vonatkozó tételek faktorát illetôen több ponton is eltérést mutatnak az előzó kutatási lépésben használt második (akkor tovább nem módosított) kérdôíváltozat eredményeihez képest. Egyfelól, míg abban a helyidentitást célzó tételeket tartalmazó faktor minden analízis esetén elsố faktorként szerepelt a struktúrában, e kutatás mindkét kérdốivváltozatában és a második változat mindkét feltáró elemzése szerint a második helyre került. Úgy tûnik tehát, hogy a „helyek” általános megfogalmazás differenciáltabbá tétele elôzetes elképzelésünknek megfelelóen hozzájárult a faktorstruktúrában elfoglalt hely megváltozásához, ugyanakkor önmagában ez nem segítette a tételek közötti hibakovarianciák eltûnését.

Míg az elốzô kutatási lépésben a faktoranalízis helyekre vonatkozó tételeket tartalmazó faktorában az erôs érzelmi szálakra vonatkozó tétel bírt a legnagyobb faktorsúlylyal (a faktor minden struktúra esetében érzelmi színezetú volt), jelen kutatás második kérdőívváltozatában e faktor legnagyobb faktorsúlyú tételévé mindkét feltáró elemzésben az énkiterjesztésre vonatkozóan átfogalmazott tétel vált, az érzelmi kapcsolatra vonatkozó tétel a második helyre került, azaz a faktorban a hely énbe történô bekerülése hangsúlyosabbá vált. Bár kutatásunk nem célozta a helyidentitás és helykötôdés általunk elfogadott viszonyának vizsgálatát, mindkét feltáró elemzés eredményében azt láttuk, hogy a helykötôdésre vonatkozó két tétel a faktorsúlya alapján nem kerül egymás mellé (nem különülnek el a többitôl), továbbá a SEM CFA eredményében a kötôdés szót explicit tartalmazó tétel hibakovarianciát mutatott a fent említett, énkiterjesztésre vonatkozó tétellel (ez egybevág Droseltis és Vignoles [2010] eredményeivel, akik az érzelmi kötődést és az énkiterjesztést egy dimenziónak tekintik a helyidentitás 
dimenziói között). Mindezek utalnak a két fogalom általunk elfogadott viszonyának helytállóságára, de e viszony explicit igazolásának nem tekinthetjük.

Érdemes kitérni két, a helyeket is említô, de más skálába tartozó tételre. A 14. tétel az eredeti angol nyelvú kérdőívben (amelyben 13. tétel) a kollektív skála része volt, a helyek szociális, közösségi vonatkozását célozta, és szerepelt is benne a „helyek” szó. (A tétel szövegezésének különbözô változatai megtalálhatók a tételmódosítások tárgyalásánál a 13. és 16. lábjegyzetben.) Míg az elôzô kutatási lépés elsô kérdôívváltozatában nem került be az általunk készített, helyekre vonatkozó tételek faktorába, a tétel módosítása utáni második változatban viszont igen. A jelen kutatásban e tételból is kivettük a helyek szót, ugyanakkor az elsố változatban megmaradt benne a helyekre vonatkozó „ahol” szó, így viszont már nem került be a helyidentitásra vonatkozó faktorba. (A második változatban a kollektív skálába történô bekerülése érdekében erôsebben hangsúlyoztuk a közösségek szerepét, így az „ahol” szó kikerült, de a további finomításban érdemes lehet visszatenni azt a diszkriminációs validitás biztosítása érdekében.) A kollektív skálába tartozó 8. (az etnikai háttérre vonatkozó) tételbe bekerült a magyar szociokulturális viszonyoknak a rassznál jobban megfelelô földrajzi-tájegységi hovatartozás, amely szintén helyvonatkozású, mégsem került be a helyidentitás faktorába.

A helyidentitás-orientáció megfelelô mérése mellett feltételeztük azt is, hogy a vizsgálatban használt angol nyelvú kérdôív a tételek módosítása után felnôtt mintán alkalmas az eredeti kérdôívben szereplô identitásorientációk mérésére, másképpen: a korábbi kutatási lépésben használt második kérdôíváltozat tételeinek módosításával az identitásorientációkat megfelelőbben és pontosabban mérô változatot kapunk. A második változat adatainak SPSS-ben elvégzett feltáró faktoranalízise során a Varimax rotáció után kapott faktorstruktúrában csupán a kollektív (az elôzô lépésben is leggyengébben múködô) skála maradt hiányos (bár így is teljesebb az elôzố lépésben kapott faktortartalomnál, azaz a kollektív tételeket érintô átfogalmazások két tétel esetében elérték céljukat), a másik három eredeti identitásorientáció faktorába minden, az eredeti kérdôív megfelelô skáláiban szereplô tétel bekerült. A Promax forgatás eredményét tekintve a személyes és a társas orientáció skálája esetében 1-1 tétel már hiányzik a mintázatmátrixban, ám a struktúramátrixban nem. A SEM-elemzések eredményei csupán a kollektív skála esetében jeleznek faktortartalmi és illeszkedési problémát. Ennek megfelelốen hipotézisünket az eredmények nagyrészt igazolják, azaz a kérdôív a helyidentitás-orientáció, és ezzel együtt a másik négy orientáció mérésére jelen formájában már alkalmazható (a kollektív orientáció esetében a különbözô feltáró módszerekkel történt faktoreredményeken alapuló megfontolások figyelembevétele mellett).

Az SPSS programmal végzett ferde és derékszögú forgatással létrejött faktorstruktúrák között az eredeti, skálába tartozó tételeket tekintve csak a fent említett 2 tétel esetében mutatkozott különbség. A faktorok közötti korrelációs értékek ugyanakkor alátámasztják a ferde forgatás használatát. A helyidentitás-orientáció más orientációkkal való kapcsolatára vonatkozó megalapozott kijelentések és következtetések a kollektív skála pontosabbá tétele és a faktortartalmi bizonytalanságok (pl. a hibakovarianciák, a tételkimaradások) megszüntetése utáni újabb faktorelemzést és skálák szerinti összehasonlítást követően lehetségesek. 
Az eredmények értelmezéséhez mindenképpen szükséges néhány fontos mozzanat említése. Elsôként a vizsgált minta jellemzôire térünk ki: míg az elsố kutatási lépésben a kérdốiv változatait egyetemi hallgatók töltötték ki, jelen kutatásban igyekeztünk a kérdőívet teljes életkori mintájú felnôttekkel kitöltetni. Ugyanakkor kényelmi mintavételt alkalmaztunk, ami ugyan biztosította a véletlen mintát, azonban nem tekinthetô reprezentatívnak sem az életkori, sem a nemi eloszlás alapján (mint láttuk, a második változatot több mint háromszor annyi nô töltötte ki, mint férfi). A kényelmi mintavétel tehát, ha az elsố kutatási lépésnél használtnál jóval kevésbé (pl. az életkori sajátosságokból fakadó tételértelmezési nehézségeknek ${ }^{19}$ tulajdonított faktortartalmi eltérések eltûntek a felnôtt minta esetében), de még korlátozza a jelen eredmények általánosíthatóságát. Annak további pontosítása után e kérdôívet, amelyet a következó kutatási lépések egyikében a helyidentitás aspektusait a személyiség szintjén mérni célzó, általunk készített kérdôívvel együtt tervezünk felvenni, a kiegyensúlyozott életkori és nemi eloszlást biztosító mintán célszerú felvennünk.

Másodikként említjük a kollektív orientációt mérô skálát, amelynek tartalmában még mindig a legnagyobb eltérés mutatkozott az eredeti és a két e kutatásban használt változat között. Ugyanakkor a faktortartalmon a korábban is alkalmazott és így összevethetôséget biztosító, SPSS-ben végzett feltáró elemzés alapján sikerült javítani, a kimaradó itemek pedig együtt, plusz tétel nélkül kerültek egy külön faktorba, a 7.-be. E 3 tétel a család (4. tétel), a jelenlegi és a gyermekkori közösség (a helyek társas vonatkozása, 14. tétel, lásd fentebb) és a helyi közösség (27. tétel, eredetiben: $M y$ feeling of belonging to my community) szerepét hangsúlyozzák az identitásban. Ez utóbbi esetében már az elôzó kutatási lépés tanulmányában is említettük, hogy a community kifejezés nehezen fordítható magyarra, és a kérdốiv szülóhazájában sok esetben erôs vallási és politikai színezete van. E külön faktor alapján úgy tûnik, hogy a közösség szó a magyar mintában a családot hívja elố elsôsorban (illetve a csoporttagság nehezebben értelmezhetô a család esetében), az pedig nincs olyan erôs komplex kapcsolatban a kollektív skála egyéb tételeiben található aspektusokkal, mint az Egyesült Államokban. Így e három tétel esetében sem az elôzô kutatási lépés második, sem pedig e kutatás elsố kérdôívváltozatának eredményei alapján történô átfogalmazás nem vezetett el oda, hogy e három tétel is bekerüljön a kollektív skálába. Az MPlus programban végzett EFA eredményei ugyanakkor árnyalják a képet, hiszen bár ebben az esetben is a kollektív skála mutatja a leggyengébb eredményt (nem szignifikáns faktortöltések, nem teljes skálatartalom), ugyanakkor a faktorstruktúra mátrixában a család, a jelenlegi és a gyermekkori közösség tételei ezzel együtt mégis a faktorba töltenek. Mindezeket figyelembe véve a kérdôív további finomításában érdemes lehet az eredeti célnak még megfelelô, de más hangsúlyú szövegezéssel módosítani ezeket a tételeket (amit megelőzhet egy olyan kutatás, amely a hazai közösségi identitás összetevôit tárja fel).

Harmadikként a megmagyarázott variancia kérdését kell említenünk. A skálán kívüli tételek törlésének a felnôtt mintán történô alkalmazhatóság mellett az is célja volt, hogy növeljük az elsô kutatási lépésben kapott alacsony megmagyarázott variancia értékét (hangsúlyozzuk, hogy az eredeti amerikai kutatás beszámolójában nem közölték a megmagyarázott variancia mértékét, így nincsen lehetôségünk összehasonlítást 
tenni). Ez a cél teljesült, azonban nem a megfeleló mértékben, hiszen az érték így is elmaradt a társadalomtudományi kutatásokban elvárható értéktól (60\%). Megfontolható, hogy az eredeti kollektív skála fent említett 3 kimaradt tételének skálába történó bekerülését célzó átfogalmazása mellett melyik még meghagyott skálán kívüli tétel kihagyása valósítható meg a megmagyarázott variancia értékének további növelése érdekében. Ezzel együtt úgy gondoljuk, hogy a kérdôív jelen változatában is alkalmas a helyidentitás-orientáció és a kapcsolati, a társas, a személyes és megfontolásokkal a kollektív identitásorientáció mérésére hazai felnôtt mintákon, de a további finomítás célja mindenképp a magyarázott variancia értékének lehetôség szerinti növelése is kell legyen.

Jelen kutatás eredményei alapján - bár a kényelmi mintavétel következtében föként a nemi eloszlás esetében elôállt aránytalanságot figyelembe kell venni az értelmezésben - (1) a helyidentitás identitásorientációként történô vizsgálatának indokoltsága megerôsítést nyert: a helyekkel való kapcsolat eltérô fontosságú a különbözó személyek esetében az énfogalom meghatározásában felnôtt mintán is, továbbá a jelen kutatás kérdôivével a korábbi kutatási lépésben használt második kérdôívváltozatnál megbízhatóbban mérhetô (2) mind a helyidentitás-orientáció, (3) mind pedig az eredeti angol nyelvú kérdôívben szereplô négy identitásorientáció (bár a kollektív skála még mutat hibákat), mégpedig (4) felnốtt, tehát nem csupán egyetemista mintán. A kutatássorozatunk következô lépésében megkezdtük a jelen kutatás második kérdôívváltozatának felvételét angol nyelven (a tételek eredeti angol megfogalmazását egy kivétellel meghagyva, a helyidentitásra vonatkozó tételeket angolra fordítva) angliai felnôtt mintán (tehát kihagyva a jelen kutatásban is kihagyott, nagyobbrészt az egyetemista mintára értelmezhetô tételeket), amelynek eredményei érdekes elméleti és pszichometriai összehasonlításokra teremthetnek majd lehetôséget. Tervezzük továbbá a kérdôív finomítását és a helyidentitás aspektusait mérni célzó saját fejlesztésû kérdốivvel egy battériában, de különállóan felvenni kiegyenlítettebb életkori és nemi arányú felnoótt mintán. Ennek eredményeképpen a helyidentitás-orientáció mögöttes aspektusainak a személyiség szintjén történô, valamint egyéb identitásorientációkkal való kapcsolatának vizsgálata, valamint az identitásorientációk különbözó életkorokban mérhetô mintázatának összevetése is megvalósulhat. Ezen elkészült kérdốvek használata és ezen vizsgálatok eredményei a gyakorlatban hozzájárulhatnak majd a személy-környezet kapcsolatban mutatkozó össze (nem) illések okainak mélyebb megértéséhez.

\section{KÖSZÖNETNYILVÁNÍTÁS}

A kutatás az ELTE Tématerületi Kiválósági Program 2020 - Intézményi Kiválósági Alprogram - TKP2020-IKA-05 keretében, illetve az ELTE PPK Pszichológiai Doktori Iskola „Doktori Projektek” konzorciális kutatás-támogatási pályázat (munkaszám: B10401/20) támogatásával valósult meg. 


\section{IRODALOM}

Bernardo, F., \& Palma-Oliveira, J. (2013). Place Identity, Place Attachment and the Scale of Place: The Impact of Place Salience. Psychology, 4(2), 167-193.

Berze, I. Zs., \& Dúll, A. (2018). Helyidentitás mint identitásorientáció? Magyar Pszichológiai Szemle, 73(3), 435-463.

Berze, I. Zs., \& Dúll, A. (2019). Módszertani megfontolások a helyidentitásorientáció méréséhez. Szimpózium-elôadás, Magyar Pszichológiai Társaság (MPT) XXVIII. Országos Tudományos Nagygyúlése. Debrecen, 2019. május 30. - június 1.

Brown, B., \& Werner, C. (1985). Social Cohesiveness, Territoriality, and Holiday Decorations: The Influence of Cul-de-sacs. Environment and Behavior, 17(5), 539-565.

Brown, T. A. (2006). Confirmatory Factor Analysis for Applied Research. New York, NY: Guilford Press.

Browne, M. V., \& Cudek, R. (1993). Alternative Ways of Assessing Model Fit. In K. A. Bollen, \& J. S. Long (Eds), Testing Structural Equation Models (pp. 136-162). Newbury Park, CA: Sage.

Canter, D. (1977). The Psychology of Place. London: Architectural Press.

Cattell, R. B. (1978). The Scientific Use of Factor Analysis. New York: Plenum.

Cheek, J. M. (1989). Identity Orientations and Self-Interpretation. In D. M. Buss, \& N. Cantor (Eds), Personality Psychology: Recent Trends and Emerging Directions (pp. 275-285). New York: Springer Verlag.

Cheek, J. M., \& Briggs, S. R. (1982). Self-Consciousness and Aspects of Identity. Journal of Research in Personality, 16(4), 401-408.

Cheek, J. M., Smith, S. M., \& Tropp, L. R. (2002). Relational Identity Orientation: A Fourth Scale for the $A I Q$. Paper presented at the Meeting of the Society for Personality and Social Psychology, Savannah, GA. Letöltve: 2020. 06. 24-én: www.researchgate.net/profile/Jonathan_Cheek/publication/267038939_RELATIONAL_IDENTITY_ORIENTATION_A_FOURTH_SCALE_ FOR_THE_AIQ_Aspects_of_Identity_Questionnaire/links/544356ec0cf2a76a3ccb1044/ RELATIONAL-IDENTITY-ORIENTATION-A-FOURTH-SCALE-FOR-THE-AIQAspects-of-Identity-Questionnaire.pdf

Cheek, J. M., \& Tropp, L. R. (2003, August 4). The Aspects of Identity Questionnaire. History and Bibliography. Letöltve: 2020. 06. 24-én: http://academics.wellesley.edu/Psychology/ Cheek/identity.html

Cheek, N. N., \& Cheek, J. M. (2018). Aspects of Identity: From the Inner-Outer Metaphor to a Tetrapartite Model of the Self. Self and Identity, 17(4), 467-482.

Comrey, A. L., \& Lee, H. B. (1992). A First Course in Factor Analysis. Hillsdale, NJ: Erlbaum.

Deaux, K. (1993). Reconstructing Social Identity. Personality and Social Psychology Bulletin, 19(1), 4-12.

Droseltis. O., \& Vignoles, V. L. (2010). Towards an Integrative Model of Place Identification: Dimensionality and Predictors of Intrapersonal-Level Place Preferences. Journal of Environmental Psychology, 30(1), 23-34.

Du, W., Litteljohn, D. \& Lennon, J. (2013). Place Identity or Place Identities: The Memorial to the Victims of the Nanjing Massacre, China. In White, L., \& Frew, E. (Eds) Dark Tourism and Place Identity: Managing and Interpreting Dark Places (pp. 46-59). Oxon: Routledge.

Dúll, A. (1996). A helyidentitásról. Magyar Pszichológiai Szemle, 36(4-6), 363-391.

Dúll, A. (2002). Ember és környezet affektív kapcsolata: a helykötôdés. Alkalmazott Pszichológia, 4(2), 49-65.

Dúll, A. (2009). A környezetpszichológia alapkérdései. Helyek, tárgyak, viselkedés. Budapest: L'Harmattan Kiadó. 
Dúll, A. (2017). Épitett környezet és pszichológia: a lokalitásélmény környezetpszichológiai vizsgálatai. Budapest: MTA doktori értekezés.

Edwards, J. R., Cable, D. M., Williamson, I. O., Lambert, L. S., \& Shipp, A. J. (2006). The Phenomenology of Fit: Linking the Person and Environment to the Subjective Experience of Person-Environment Fit. Journal of Applied Psychology, 91(4), 802-827.

Erikson, E. H. (1991). A fiatal Luther és más írások. Budapest: Gondolat Kiadó.

Fenigstein, A., Scheier, M. F., \& Buss, A. H. (1975). Public and Private Self-Consciousness: Assessment and Theory. Journal of Consulting and Clinical Psychology, 43(4), 522-527.

Gorsuch, R. L. (1983). Factor Analysis (2nd ed.). Hillsdale, NJ: Erlbaum.

Greenwald, A. G., \& Pratkanis, A. R. (1984). Az én. In J. László (Ed.), (1992). Válogatás a szociális megismerés szakirodalmából II. (pp. 205-252). Budapest: Tankönyvkiadó.

Guilford, J. P. (1954). Psychometric Methods (2nd ed.). New York: McGraw-Hill.

Hair, J. F., Black, W. C., Babin, B. J., \& Anderson, R. E. (2010). Multivariate Data Analysis. Seventh Edition. Upper Saddle River, New Jersey: Prentice Hall.

Hauge, Å. L. (2007). Identity and place: A Critical Comparison of Three Identity Theories. Architectural Science Review, 50(1), 44-51.

Hernández, B., Hidalgo, M. C., Salazar-Laplace, M. E., \& Hess, S. (2007). Place Attachment and Place Identity in Natives and Non-Natives, Journal of Environmental Psychology, 27, 310-319.

Hinds, J., \& Sparks, P. (2008). Engaging with the Natural Environment: The Role of Affective Connection and Identity. Journal of Environmental Psychology, 28, 109-120.

Hummon, D. M. (1992). Community Attachment: Local Sentiment and Sense of Place. In I. Altman, \& S. M. Low (Eds), Place Attachment (pp. 253-278). New York: Plenum Press.

IBM Corp. Released (2019). IBM SPSS Statistics for Windows. Version 26.0. Armonk, NY: IBM Corp.

Jones, S. R., \& McEwen, M. K. (2000). A Conceptual Model of Multiple Dimensions of Identity. Journal of College Student Development, 41, 405-414.

Jorgensen, B. S., \& Stedman, R. C. (2001). Sense of Place as an Attitude: Lakeshore Owners Attitudes toward Their Properties. Journal of Environmental Psychology, 21, 233-248.

Kaplan, S. (1983). A Model of Person-Environment Compatibility. Environment and Behavior, 15(3), 311-332.

Kline, R. B. (2005). Principles and Practice of Structural Equation Modeling. New York, NY: Guilford Press.

Knez, I. (2014). Place and the self: An Autobiographical Memory Synthesis. Philosophical Psychology, 27(2), 164-192.

Knez. I., \& Eliasson, I. (2017). Relationships Between Personal and Collective Place Identity and Well-Being in Mountain Communities. Frontiers in Psychology, 8, 1-12.

Korpela, K. M. (1989). Place-Identity as a Product of Environmental Self-Regulation. Journal of Environmental Psychology, 9, 241-256.

Kyle, G., Graefe, A., \& Manning, R. (2005). Testing the Dimensionality of Place Attachment in Recreational Settings. Environment and Behavior, 37, 153-177.

Lalli, M. (1992). Urban-related Identity: Theory, Measurement, and Empirical Findings. Journal of Environmental Psychology, 12, 285-303.

Manzo, L. C. (2003). Beyond House and Haven: Toward a Revisioning of Emotional Relationships with Places. Journal of Environmental Psychology, 23, 47-61.

MacCallum, R. C., Widaman, K. F., Zhang, S., \& Hong, S. (1999). Sample Size in Factor Analysis. Psychological Methods, 4, 84-99.

Miller, D. R. (1963). The Study of Social Relationships: Situation, Identity, and Social Interaction. In Koch, S. (Ed.), Psychology: A Study of a Science. New York: McGraw-Hill, Vol. 5. 
Muthén, L. K., \& Muthén, B. O. (1998-2017). Mplus User's Guide. Los Angeles, CA: Muthén \& Muthén.

Neisser, U. (1988). Az önmagunkról való tudás öt válfaja. In J. László (Ed.), (1992). Válogatás a szociális megismerés szakirodalmából II. (pp. 173-204). Budapest: Tankönyvkiadó.

Oyserman, D., Elmore, K., \& Smith, G. (2012). Self, Self-Concept, and Identity. In Leary, M. R., \& Tangney, J. P. (Eds), Handbook of Self and Identity (pp. 69-104). New York: The Guilford Press.

Phillips, D. R., Cheng, K. H. C., Yeh, A. G. O, \& Siu, O-L. (2010). Person-Environment (P-E) Fit Models and Psychological Well-Being among Older Persons in Hong Kong. Environment and Behavior, 42(2), 221-242.

Proshansky, H. M. (1978). The City and Self-Identity. Environment and Behavior, 10(2), 147-169.

Proshansky, H. M., Fabian, A. K., \& Kaminoff, R. (1983). Place-Identity: Physical World Socialization of the Self. Journal of Environmental Psychology, 3, 57-83.

Qualtrics (2005-2020). Qualtrics Survey Software. Provo, UT, USA.

Rollero, C., \& De Piccoli, N. (2010). Place Attachment, Identification and Environment Perception: An Empirical Study. Journal of Environmental Psychology, 30, 198-205.

Sampson, E. E. (1978). Personality and the Location of Identity. Journal of Personality, 46(3), 552-568.

Sedikides, C., \& Brewer, M. B. (2001). Individual Self, Rational Self, and Collective Self. Partners, Opponents, or Strangers? In C. Sedikides, \& M. B. Brewer (Eds), Individual Self, Relational Self, Collective Self (pp. 1-6). Philadelphia: Psychology Press.

Stokols, D., \& Shumaker, S. A. (1981). People in Places: A Transactional View of Settings. In Harvey, J. H. (Ed.), Cognition, Social Behavior, and the Environment (pp. 441-489). Hillsdale: Lawrence Erlbaum.

Twigger-Ross, C. L., \& Uzzell, D. L. (1996). Place and Identity Processes. Journal of Environmental Psychology, 16, 205-220.

Twigger-Ross, C. L., Bonaiuto, M., \& Breakwell, G. (2003). Identity Theories and Environmental Psychology. In M. Bonnes, T. Lee, \& M. Bonaiuto (Eds), Psychological Theories for Environmental Issues (pp. 203-233). Aldershot: Ashgate.

Wiles, J. L., Allen, R. E. S., Palmer, A. J., Hayman, K. J., Keeling, S., \& Kerse, N. (2009). Older People and Their Social Spaces: A Study of Well-Being and Attachment to Place in Aotearoa New Zealand. Social Science \& Medicine, 68, 664-671.

Williams, D. R., \& Roggenbuck, J. W. (1989). Measuring Place Attachment: Some Preliminary Results. In L. H. McAvoy, \& D. Howard (Eds), Abstracts of the 1989 Leisure Research Symposium (p. 32). Arlington, VA: National Recreation and Park Association. 


\title{
MEASURING PLACE IDENTITY AS IDENTITY ORIENTATION
}

\author{
BERZE, IVÁN ZSOLT - DÚLL, ANDREA
}

In the second stage of our research series examining the environmental psychology's concept of place identity, as a new approach, in personal psychological framework, we hypothesized that our questionnaire developed based on the results of the first measurement with undergraduate subjects (Berze, \& Dúll, 2018) can reliably measure place identity as identity orientation (i.e., the individual differences in the extent to which the relationship with places is important for the individuals to their sense of who they are) in an adult sample, in addition, that the four (personal, social/public, collective and relational) identity orientations of the original US questionnaire (AIQ-IV, Cheek, Smith, \& Tropp, 2002) can be more effectively measured with our new questionnaire than with our previous one in the sample of this study.

Methods: We modified the second version of AIQ-IV translated into Hungarian and extended with the items relating to place identity, which we used in our previous step, based on professional and methodological considerations followed from its results. We tested two versions of the modified questionnaire in adult samples $(n=177,432)$, and we conducted factor analysis in both cases. We developed the second version after the revision of the first version used in this research, based on the results.

Results: The adequateness of measuring place identity as identity orientation was confirmed by the statistical analysis of the modified questionnaire's data collected in the adult sample. In addition, with the modifications of the questionnaire used in the previous research stage we largely achieved our aims, since the factor struct70ure of the second version of this research more exactly fit to the scale structure of the original questionnaire.

Discussion: The results represent another step towards a more subtle interpretation of the concept of place identity. We started to test this second version in UK adult sample. Our future aim is to refine the Hungarian version, and to test the refined version together with a questionnaire measuring the aspects of place identity in personal psychological framework in age- and gender-balanced adult sample.

Keywords: place identity, (self-)identity, self-concept, identity orientation, questionnaire development

A cikk a Creative Commons Attribution 4.0 International License (https://creativecommons. org/licenses/by/4.0/) feltételei szerint publikált Open Access közlemény, melynek szellemében a cikk bármilyen médiumban szabadon felhasználható, megosztható és újraközölhetô, feltéve, hogy az eredeti szerzô és a közlés helye, illetve a CC License linkje és az esetlegesen végrehajtott módosítások feltüntetésre kerülnek. (SID_1) 